\title{
Effect of an Educational Program based on Coping Strategies Enhancement on the Dimensions of Auditory Hallucinations as a psychotic symptoms
}

\author{
Shaimaa Mosad El-Refaay \\ Demonstrator in Psychiatric and Mental health Nursing, \\ Faculty of Nursing, Tanta University
}

Prof.Dr. Rahma Soliman Bahgat

Professor of Pediatric Nursing

Faculty of Nursing, Tanta University

\author{
Dr. Hala Ahmed El-Sayes \\ Lecturer of Psychiatric and Mental Health Nursing, \\ Faculty of Nursing Tanta University
}

\begin{abstract}
Auditory hallucinations are prominent feature of psychosis that can threaten, disturb, command and capture voice-hearers in a demoralizing cycle of dependence, isolation and destructive activities. Fortunately, there are many coping strategies that voice-hearers can use to challenge these voices, impose their own limits and thus regain some control. The aim of the study was evaluate the effect of an educational program based on coping strategies enhancement (CSE) on the dimensions of auditory hallucinations as a psychotic symptoms . The study sample consisted of 50 Psychiatric inpatients having auditory hallucinations, able to communicate relevantly and who are hospitalized at Tanta Mental Health Hospital that is affiliated to the Ministry of Health and Population . A quasi-experimental design was utilized. Three tools were used for data collection: Socio-demographic and Clinical data sheet, Auditory Hallucination Rating Scale used to measure various dimensions of hallucination and a Structured interview schedule of self management of auditory hallucinations. The results revealed that there was a statistically significant improvement between mean score of hallucination and total coping score before implementation of the program, immediately and after one month of implementation. The study concluded : A marked decrease in the allover damnation of auditory hallucination of the studied patients as the result of receiving an educational program about enhancing different coping strategies to cope with auditory hallucinations . Recommended: develop and implement educational programs for nurses about auditory hallucinations and coping strategies to deal with it .
\end{abstract}


Key words : Coping Strategy, Enhancement, Auditory Hallucinations.

\section{Introduction}

Auditory hallucinations, also known as paracusia, are those in which a person begins hearing non-existent voices and sounds while in a conscious state. Auditory hallucinations range from muffled sounds to complete conversations. ${ }^{(1-3)}$ The severity of auditory hallucinations varies among affected individuals, ranging from" very mild" causing individuals to not burdened by them to be "severe enough" to disturb their daily functioning. Hallucinating voices may "talk about", or" to the person", and may involve several speakers with distinct personalities. ${ }^{(4,5)}$.

Phenomenological auditory hallucinations are quite heterogeneous in nature: varying from first to second to third person commentary; from brief utterances of simple sounds or single words to full conversations; consisting of voices (the average is three) from familiar, personal and repeated to the unknown; from passive discussion to issuing commands; and from pleasant or compliment to far more commonly unpleasant and distressing. Auditory hallucinations may be experienced as coming through the ears, in the mind or anywhere in external space. Several studies found that auditory hallucinations occur either internally or externally or from both locations. ${ }^{(6-9)}$

The frequency of auditory hallucinations can range from low (once a month or less) to continuously all day long. Loudness also varies, from whispers to shouts. Duration lasts from a few seconds to several hours. The content of voices is usually highly personalized. The intensity and frequency of symptoms fluctuate during the illness, but the factor that determines whether auditory hallucinations are a central a feature of the clinical picture is the degree of interference with activities and mental functions. ${ }^{(10)}$

Auditory hallucinations cause high levels of stress. The content and the experience of intrusive and personal voices can cause distress to the individual and can cause social withdrawal and isolation. Patients may feel that they are unable to escape from the experience, and this feeling is persistent and beyond a voluntary control. ${ }^{(11-15) .}$ Affective symptoms, including depression, anxiety, fear and anger have been found in $25 \%-40 \%$ of hallucinating patients. Some patients have committed suicide to escape from the voices. Although psychotropic medications produce the most potent effect on auditory hallucinations. $25 \%$ to $30 \%$ of auditory hallucinations are "persistent". ${ }^{(15,16)}$ Persistent hallucinations affect the person's ability to engage in work, leisure, and self-care tasks. For some patients with persistent psychotic illness, hallucinations are directly responsible for the profound dysfunction in all 
aspects of daily life . Such patients find it difficult to engage in meaningful tasks or relationships. Fortunately, there are many coping strategies voice-hearers can use to challenge the voices, impose their own limits and thus regain some control. ${ }^{(17,18)}$

Coping strategies have been demonstrated to be an effective adjunctive therapy to medications and can significantly decrease the negative characteristics of this distressing symptoms, divert patients attention away from the voices, help patients to gain some control over hallucinated voices, help patients follow regular daily activities more effectively as well as assist them not to use maladaptive ways to deal with auditory hallucinations. ${ }^{(18,19)}$. Falloon and Talbot (1981)were amongst the first to study coping in relation to hallucinations and divided coping strategies into 3 main categories: behavioral strategies, changes in physiological arousal; either a reduction or increase and cognitive strategies. ${ }^{(20)}$

Physiological coping strategies include that techniques that alter patients physiological state, either to reduce autonomic arousal involve relaxation methods such as an attempt to lay down/ relax ,meditation ,taking warm bath ,deep breathing or progressive relaxation exercises or arousal increasing technique as practicing physical exercises, walking, running, listening to stimulating music. Another method is taking prescribed medications. ${ }^{(21-23)}$ Cognitive coping strategies include techniques involving mental processes . It is based on the recent cognitive conceptualizations of auditory hallucinations that involve challenging the interpretations of voices and modifying the focus of attention such as repeating short sentences and/ or counting numbers sub vocally, reading aloud, using self- instruction (telling oneself that the voices are imaginary, asking oneself to calm down). Another cognitive techniques include using self monitoring logs for recording auditory hallucinations. ${ }^{(16,23,24)}$

Behavioral coping strategies are those in which the patients describe themselves consciously doing something in response to hallucinations. These include distraction techniques as watching television, using ear plug, change one posture, keeping busy with an enjoyable activity, praying, singing, do any religious activities, painting ,play game, helping others and increasing socialization which involves initiating interpersonal contact. Seeking medical help was another commonly used coping strategy. ${ }^{(25-28)}$

These coping strategies help hallucinating patient follow regular daily activities more effectively as well as assist them not using maladaptive ways to deal with auditory hallucinations. In addition, the nurse can empower patients to take care of themselves and enhance patients' confidence in their abilities to manage their auditory hallucinations by nurse can teaching them these strategies. ${ }^{18,29-32)}$.

Nurses are in an ideal position to facilitate coping with voices through teaching, coaching, and counseling roles. Intervening when a client experiences hallucinations requires the nurse to focus on what is real and to help shift the client's response towards reality. Psychiatric nurses have several responsibilities in dealing 
with hallucinations. ${ }^{(33,34)}$ The nurses can play a crucial role as a trusted persons with whom the patients can discuss and validate their perceptions. Establishing clear, consistent open communication and providing a safe therapeutic environment also play an important role in reinforcing coping strategies and maximizing a person's sense of control over their hallucinatory experience. ${ }^{(35)}$

\section{The aim of the study is to:}

Evaluate the effect of an educational program based on coping strategies enhancement on the dimensions of auditory hallucinations as a psychotic symptom

\section{Research Hypothesis}

- Psychiatric patients coping strategies with auditory hallucinations are enhanced after the implementation of an educational program of coping strategies for auditory hallucinations.

- Dimensions of Auditory hallucinations as a psychotic symptom are improved after an educational program among psychiatric patients.

\section{Materials and Method}

\section{Materials}

Research design: A quasi-experimental research design was used.

\section{Setting:}

The study was conducted at Tanta Mental Health Hospital and population which is affiliated to the Ministry of Health with a capacity of 75 beds divided into three wards for men (50 beds) and two wards for women (25 beds) and provides health care services to Gharbya, Menofia, and Kafr ElSheikh governorates.

\section{Subjects:}

The target population of this study consisted of 50 Psychiatric inpatients( according to power analysis equation), ( 34 patients have schizophrenia,12 patients have bipolar disorders and 4 patients have depression, who fulfilled the following inclusion criteria ;Age from 18-65 years ,both sexes, having auditory hallucinations, able to communicate relevantly and willing and agreeing to participate in the study.

- Data were collected over a period of 6 months starting from August 2014 to January 2015).

\section{Tools of data collection:}

The data of this study will be collected by using the following tools:

\section{Tool I: Socio-demographic characteristics and Clinical Data Sheet.}

The tool was developed by the researcher to elicit the socio-demographic data about the study sample as age, sex, marital status, level of education, occupation, 
residency, living condition as well as clinical data of the patients as diagnosis, age of onset of psychotic illness, number of previous psychiatric hospitalizations, duration of current hospitalization .

\section{Tool II: Auditory Hallucination Rating Scale .}

A scale developed by (Gillian Hadook 1994) ${ }^{(36)}$. It consists of 11 items that measure various dimensions of hallucinations (frequency, duration, location, control \& loudness of auditory hallucinations, origin of voice, disruption of daily life, amount of distress due to auditory hallucinations, intensity of distress due to auditory hallucinations amount of negative content and degree of negative content.)

Each item is scored from 0 to 4 .The hallucination severity score therefore ranged from 0 to 44 where 0 indicates absence of auditory hallucinations and 44 indicating sever auditory hallucinations. Evaluation of this scale will be as follow: $<50 \%=$ Mild auditory hallucinations, $50-75 \%=$ Moderate auditory hallucinations and $>75 \%=$ Severe auditory hallucinations.

Tool III: Structured Interview Schedule related to Self management of auditory hallucinations.

The tool developed by (Eman S. Abd Elhay 2008) ${ }^{(25)}$. It was used to elicit information in relation to self management of auditory hallucinations. It includes 36 items of coping strategies that are divided into three categories:

a) Physiological category which includes 7 strategies either to reduce patient's arousal that is divided into three negative strategies such as sleeping, taking extra medication, listening to soft music and one positive strategy such as lying down /rest and strategies to increase patient's arousal which include one negative strategy such as smoking cigarette and two positive strategies such as doing exercise and walk.

b) Cognitive category which includes 11 strategies that are divided into three negative strategies such as reacting/talking with the voices ,listening to voices , shooting and screaming at the voices and eight positive strategies such as asking self to calm down, ignoring them, clarifying voices and saying to oneself it isn't true, saying" go away" and "stop to voices", thinking in another thing except voice, reading aloud, selective listening to voices ,repeating short sentences and /or counting numbers subvocally.

c) Behavioral category which includes 18 strategies that are divided into 7 negative strategies such as isolating oneself, going to crowded places ,crying, masturbating, hurting oneself, eating and do as the voices say and 11 positive strategies such as blocking ears, watching television with loud voices ,seeking help from nurses and doctors ,talking to others, praying, singing ,drawing ,playing cards, doing any tasks, changing one's posture and leaving places .

Each item is scored ( by researchers) from 0 to 3 , where $0=$ No coping, $1=$ didn't help , $2=$ help to some extent, $3=$ help a lot . The minimum score for these tool is 0 and the maximum score is 108. Evaluation of this scale will be as follow: $<50 \%$ 
$=$ Unsuccessful coping, $50-75 \%=$ Partial successful coping and $>75 \%$ $=$ Successful coping.

Method: official approval was obtained from the identified hospital to collect the study data.

Ethical consideration: Written consent was obtained from the patient or the patient's family after the explanation of the aim of the study.

Patients' privacy and data confidentiality were assured and kept.

Patient's right to withdraw from the study at any phase was respected.

- Tool I was developed by the researcher.

- Tool II (Auditory Hallucination Rating Scale)was translated into Arabic language by the researchers.

- Tool III (Structured interview schedule of self-management of auditory hallucinations) , the score are added by researchers through statistics expert .

- Tools II and III were be tested content validity by a group of 5 experts in the psychiatric field.

- A pilot study was conducted on 10 psychotic patients out of the proposed sample after taking their approval to test the feasibility and applicability of the study tools, and determining obstacles that may be encountered during the period of data collection, after its implementation and according to the results, some statements of tool II( No 5,10,11)needed rewarding and are retested.

- Internal consistency of the study tools II\&III was done by means of Cronbach's Alpha coefficient, which yielded values of $r=0.9421-r=0.9325$ respectively.

- The actual study which was divided into four phases :

- Assessment Phase:-

- The researcher reviewed all psychiatric inpatients' records in order to select those who meet inclusion criteria.

- The recruited patients were asked to participate in the study after establishing rapport and trusting relationship and explaining the aim of the study. The process continued till desired subjects number (50 patients) was reached.

- The recruited patients undergone a pre-test using Socio-demographic and clinical data sheet. Auditory Hallucination Rating scale and the Structured 
Interview schedule of self-management of auditory hallucinations . this was applied through interviewing patients on an individual basis by the researcher.

- Each interview lasted for 30-45 minutes, according to the patient's attention, concentration, willingness to co-operate or talk. Patient's clinical data were double checked from their clinical charts.

\section{- Program development phase}

- The program was developed by the researchers based on data from the assessment phase and literature review. The program content was developed. the content stressed mainly on the different coping strategies enhancement ( physiological, cognitive and behavioral ) and apply it to cope with auditory hallucinations as the psychotic symptoms and improve its characteristic

- The program objective was settled. The suitable educational strategies selected according to session content .

- General objective: to enhance coping strategies and practice it with auditory hallucinations.

- Specific objective :by the end of this program ,the patients will be able to: Recognize purpose of the program; list importance coping with auditory hallucinations ; List the different types of coping strategies; Apply these coping with auditory hallucination ; apply different activities as Listening to music, drawing and painting, singing to cope with the voices

- The program was developed on a small group basis. Each sub group encompassed 5 patients. Each subgroup attended a total of 5 sessions. These sessions were scheduled as 2 sessions per week for a duration of about $2^{1 / 2}$ weeks and one session in third week .The total hour of the session was approximately 10 hours. The sessions was planned to conduct inside the patient's ward.

- The researcher prepared essential materials for conducting the program such as writing papers, cards, chess, dominoes ,different size of papers for drawing and painting, water colors,pens ,pencils,brushes, journals, books, cottons, religious books ,colorful magazines ,puzzles and laptops.

\section{- Implementation Phase:-}

- Before implementation of the program, permission was obtained through official letters to secure approval about agenda of the program, place and time performing was arranged with hospital administrator and staff in order not to interfere with their work.

- The researchers divided the implementation phase of the program into two parts which includes 5sessions. During each session, The participants are given break for 10 minutes.

-Part I. It includes 3 educational sessions as the following : 
-First Session: lasted for one hour, it was an introductory session that emphasizes acquaintance between the group members ( 5 patients ) as well as the researcher and also an explanation of the program purpose and importance of coping strategies to ensure that the patients understand the program.

-Second Session: This session lasted 2.30 hours. It Covered the topics:"physiological and cognitive coping strategies explanation and the application of such strategies. Some strategies supported by videos. Also, The researchers helped the patients to practice physical exercises with listening to stimulate music

-Third session: This session lasted 2.30 hours , it covered the topic :"Behavioral coping strategies explanation and its applications". it was supported by videos. During this session the researcher regulates drawing/painting, singing competition with patients . Group activity such as playing cards, dominoes, puzzles and any preferable activity as watching TV, praying and talking with others are used

-Part II: Training exercises are done to help patients to cope with stress, which may act as triggers for hallucinations which include:

-Fourth Session: This session lasted one hour. It Covered the topic "Deep breathing exercise, explanation steps of these exercises and it was supported by videos, demonstration and re demonstration of these exercises.

- Fifth Session: This session lasted 2 hours. It Covered the topic "progressive relaxation technique ", explanation steps of these exercises and it was supported by videos and pictures about it,demonstration and re demonstration of these exercises .

\section{- Evaluation Phase:}

The evaluation of the implemented program was done by:

-Reapplying of Auditory Hallucination Rating Scale and Structured interview schedule of self - management of auditory hallucinations was done as follows:

-Immediately after the implementation of the program (post test 1).

-One months later after the program implementation (post test 2).

\section{Statistical Analysis:}

The collected data were organized, tabulated and statistically analyzed using SPSS version 19 (Statistical Package for Social Studies) created by IBM, Illinois, Chicago, USA. For numerical values, the range mean and standard deviations were calculated. The differences between two mean values were compared using student's t test. Differences of mean values between more than two groups were tested by analysis of variance (F) test ,followed by Bonferroni test whenever result was significant. The relations between quantitative variables were tested by Pearson's correlation coefficient $(\mathrm{r}$ ). The level of significance was adopted at $\mathrm{p}<0.05$. For categorical variable, the number and percentage were calculated the associations and between variables were tested by chi square $\left(\mathrm{X}^{2}\right)$. 


\section{Results}

Table (1):-Shows that most patients were male ( 68\%). The highest percentage of the studied patients $(58 \%)$ had age ranging between 20 to 35 years. Concerning the patient's occupational status, it was observed that $56 \%$ of the studied subjects were unemployed and $28 \%$ of the studied patients were illiterate .In relation to their residency $62 \%$ were living in rural areas. Regarding their marital status $50 \%$ of the subjects were singles .The table also shows that $38 \%$ of the studied patients who live with their relative, $34 \%$ live with family and $28 \%$ of the patients live alone.

Table (2): illustrate the distribution of the studied patients according to their clinical data. It reveals $68 \%$ of the studied patients had schizophrenia and $24 \%$ had mania. Regarding patient's age at onset of the disease, $32 \%$ of the studied patients were in the age from 20 years to less than 25 years and $28 \%$ in the age from 25 years to less than 30 years . Regarding the number of hospital admissions, $62 \%$ of the studied patients were admitted 4 times or more, while $38 \%$ were admitted only once. In relation to the current length of hospital stay , $48 \%$ were staying in the hospital for less than 3 months.

Figure 1: Illustrates that $38 \%$ of the patients have been hallucinating for 5 to less than 10 years, while only $28 \%$ of the patients for less than 5 year.

Table (3):- This table shows dimensions auditory hallucinations of studied sample. It reveals that $52 \%$ of the studied patients had a frequency of auditory hallucinations once per an hour before intervention, while $58 \%$ of them had a frequency of auditory hallucinations once per a day immediately after intervention and $46 \%$ once per a day after one month. Significant difference was observed between the improvements the frequency of auditory hallucination and implantation coping strategies from before intervention, immediately and after one month of intervention $\left(\chi^{2}=55.78, \mathrm{P}<0.05\right)$.

Concerning e degree of negative content of voice, $38 \%$ of the studied patients reported that voices content includes personal verbal abuse before intervention. Immediately after intervention, $42 \%$ of them reported that voices content includes verbal comments on behavior. After one month of intervention, only $6 \%$ of the studied patients reported that voices content includes personal threat to harm them. The Significant difference was present regarding the degree of negative content of voices $\left(\chi^{2}=45.76, \mathrm{P}<0.05\right)$.

Table 4:- Represents the physiological coping strategies as reported by the studied patients. It shows that $54 \%$ of the studied patients used sleeping as a technique for dealing with voices before intervention while immediately after the intervention, $30 \%$ of them used this technique. After one month of intervention, $84 \%$ of patients didn't use sleeping as a technique for dealing with voices. There is a statistically significant 
relation between sleeping as coping strategies and educational program before, immediately and after the implementation at the level of $\left(\chi^{2} 25.13, \mathrm{P}<0.05\right)$.

This table also shows that there is a statistically significant relation between smoking cigarettes using as coping strategies auditory hallucination for before training program and after implementation at the level of $\left(\chi^{2} 25.27, \mathrm{P}<0.05\right)$.

Table (5): This table reflects that there was a significant improvement in the method of cognitive strategies as (say go away and stop to voices, read aloud,think of another thing except voice) from before intervention, immediately and after one month of the educational program where $\left(\chi^{2}=24.82,11.04,45.92\right.$ respectively $)$ and $(\mathrm{P}<0.05)$.

Table (6) :Concerning the studied patients who used talk with someone /friend to cope with voices, the table demonstrates that $12 \%$ of them used this technique before intervention to cope with voices. After one month of intervention, $78 \%$ of the studied patients used this way to cope with voices and $58 \%$ of them reported that it helped them to some extent. There is statistically significant relation between using talk with someone/friend as coping strategies before, immediately and after the implementation program at level of $\left(\chi^{2} 49.10, \mathrm{P}<0.05\right)$.

Table (7): The table reveals that appears that $88 \%$ of the patients practice deep breathing exercise to immediately after intervention and $32 \%$ of them reported that it helps them a lot. After one month of intervention $68 \%$ of the studied patients practice deep breathing exercises. the significant relation was observed between practice deep breathing exercises as coping strategies before program and after the training program implementation at level of $\left(\chi^{2}=70.32, \mathrm{P}<0.05\right)$.

Table (8): illustrates the comparison between the total scores of hallucination and different types of coping strategies before, immediately and after intervention. It was present that $64 \%$ of study patients had moderate hallucination which decreased to $20 \%$ after implementation the program and $28 \%$ of them suffered from severe hallucination which decreased to only $8 \%$ after training program.

Also significant differences was observed between patients' mean scores of successful coping to different strategies as physiological, cognitive and behavior coping strategies before and after the implementation of training program $\left(\chi^{2}=48.054,29.314,54.526, \mathrm{P}<0.05\right)$ respectively

Table (9): This table shows the relation between socio-demographic and clinical characteristics of the studied patients and their total mean score of hallucination. The results reveals that there is a statistically significant relationship between mean hallucination score and clinical diagnosis While there is no 
statistically significant relation between ages, sex, residence, level of education ,marital status and occupation of the studied patients and their total mean score of hallucinations

The table also reveals that there is a statistically significant relationship between behavioral coping score and educational level in which $\mathrm{t}=4.291$ and $\mathrm{P}$ value $=0.020$ while there is no statistically significant relation between age, gender, residence, employment, marital status and clinical diagnosis of the studied patients and their mean behavioral coping scores.

Table (10): This table revealed that there is a statistically significant and negatively co relation between the age at onset of illness of study patients and he mean score of behavioral coping $(r=-0.362, p<0.05)$. There is a statistically significant relationship between the age at onset of illness of the studied patients and the total coping score $(\mathrm{r}=-0.295, \mathrm{p}<0.05)$. while no observe any significant relation between number of hospital admission, current duration of hospitalization and the mean scores of different coping strategies used to control the hallucination . 
Table (1): Percentage distribution of the studied patients according to Sociodemographic characteristics.

\begin{tabular}{|c|c|c|}
\hline \begin{tabular}{|l|} 
Socio-demographic \\
\end{tabular} & The studied p & \\
\hline characteristics & No & $\%$ \\
\hline Age in years: & & \\
\hline 20 & 29 & 58.0 \\
\hline $35-$ & 13 & 26.0 \\
\hline $50+$ & 8 & 16.0 \\
\hline Range & $21-62$ & \\
\hline Mean+SD & $37.30+11.42$ & \\
\hline Sex: & & \\
\hline Male & 34 & 68.0 \\
\hline Female & 16 & 32.0 \\
\hline Occupation : & & \\
\hline Unemployed & 28 & 56.0 \\
\hline Manual Worker & 16 & 32.0 \\
\hline Employee & 4 & 8.0 \\
\hline Retired & 2 & 4.0 \\
\hline Educational level: & & \\
\hline Illiterate & 14 & 28.0 \\
\hline Read and write & 11 & 22.0 \\
\hline Preparatory school & 8 & 16.0 \\
\hline Secondary school & 10 & 20.0 \\
\hline High education & 7 & 14.0 \\
\hline Residency: & & \\
\hline Rural & 31 & 62.0 \\
\hline Urban & 19 & 38.0 \\
\hline Marital status: & & \\
\hline Single & 25 & 50.0 \\
\hline Married & 18 & 36.0 \\
\hline Divorced & 5 & 10.0 \\
\hline Separate & 2 & 4.0 \\
\hline \begin{tabular}{|l|} 
Living accommodation: \\
\end{tabular} & & \\
\hline Alone & 14 & 28.0 \\
\hline With family & 17 & 34.0 \\
\hline With relative & 19 & 38.0 \\
\hline
\end{tabular}


Table (2): Percentage distribution of the studied patients according to clinical characteristics

\begin{tabular}{|c|c|c|}
\hline \multirow[t]{2}{*}{ clinical characteristics } & \multicolumn{2}{|c|}{ The studied patients $(\mathrm{n}=50)$} \\
\hline & $\mathbf{N}$ & $\%$ \\
\hline $\begin{array}{l}\text { Diagnosis: } \\
\text { Schizophrenia } \\
\text { Mania } \\
\text { Depression }\end{array}$ & $\begin{array}{l}34 \\
12 \\
4\end{array}$ & $\begin{array}{l}68.0 \\
24.0 \\
8.0\end{array}$ \\
\hline $\begin{array}{l}\text { Age at onset of the disease: } \\
<20 \\
20- \\
25- \\
30+\end{array}$ & $\begin{array}{l}11 \\
16 \\
14 \\
9\end{array}$ & $\begin{array}{l}22.0 \\
32.0 \\
28.0 \\
18.0\end{array}$ \\
\hline $\begin{array}{l}\text { Range 17-55 } \\
\text { Mean+SD } \quad 26.40+10.03\end{array}$ & & \\
\hline $\begin{array}{l}\text { Number of hospital } \\
\text { admissions: } \\
<2 \text { times } \\
\text { 2- times } \\
\text { 4- and more }\end{array}$ & $\begin{array}{l}15 \\
4 \\
31 \\
\end{array}$ & $\begin{array}{l}30.0 \\
8.0 \\
62.0 \\
\end{array}$ \\
\hline $\begin{array}{ll}\text { Range } & 1-30 \\
\text { Mean+SD7.04+6.27 } \\
\text { Median } \quad 5\end{array}$ & & \\
\hline $\begin{array}{l}\text { Length of hospital staying } \\
\text { in month: } \\
<3 \\
3- \\
6- \\
9- \\
12+\end{array}$ & $\begin{array}{l}24 \\
20 \\
3 \\
2 \\
1\end{array}$ & $\begin{array}{l}48.0 \\
40.0 \\
6.0 \\
4.0 \\
2.0\end{array}$ \\
\hline $\begin{array}{l}\text { Range } 1-13 \\
\text { Mean+SD } 3.22+2.4 \\
\text { Median } 3\end{array}$ & & \\
\hline
\end{tabular}


Figure (1): Distribution of the studied patients according to the duration of auditory hallucinations.

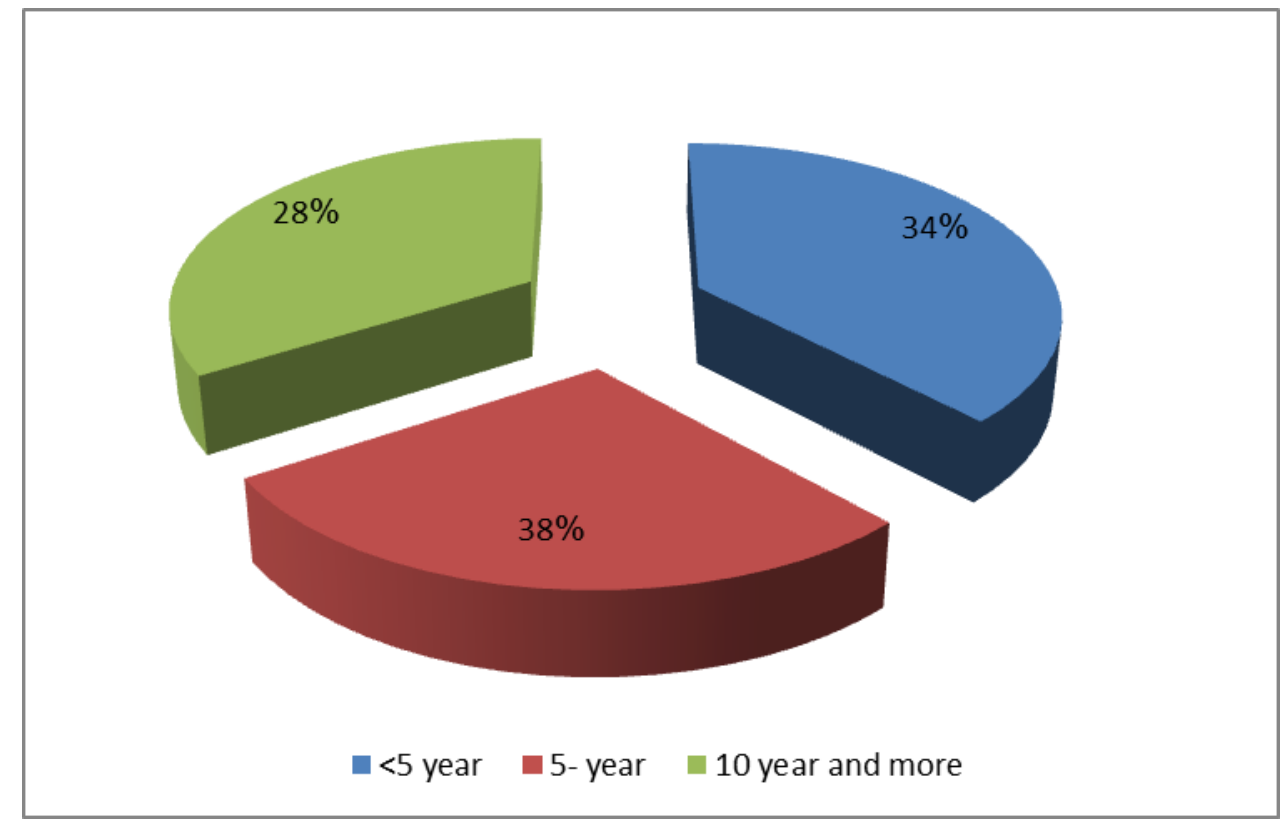


Table (3): Percentage distribution dimensions of auditory hallucinations among the studied patients before, immediate and after intervention $(n=50)$.

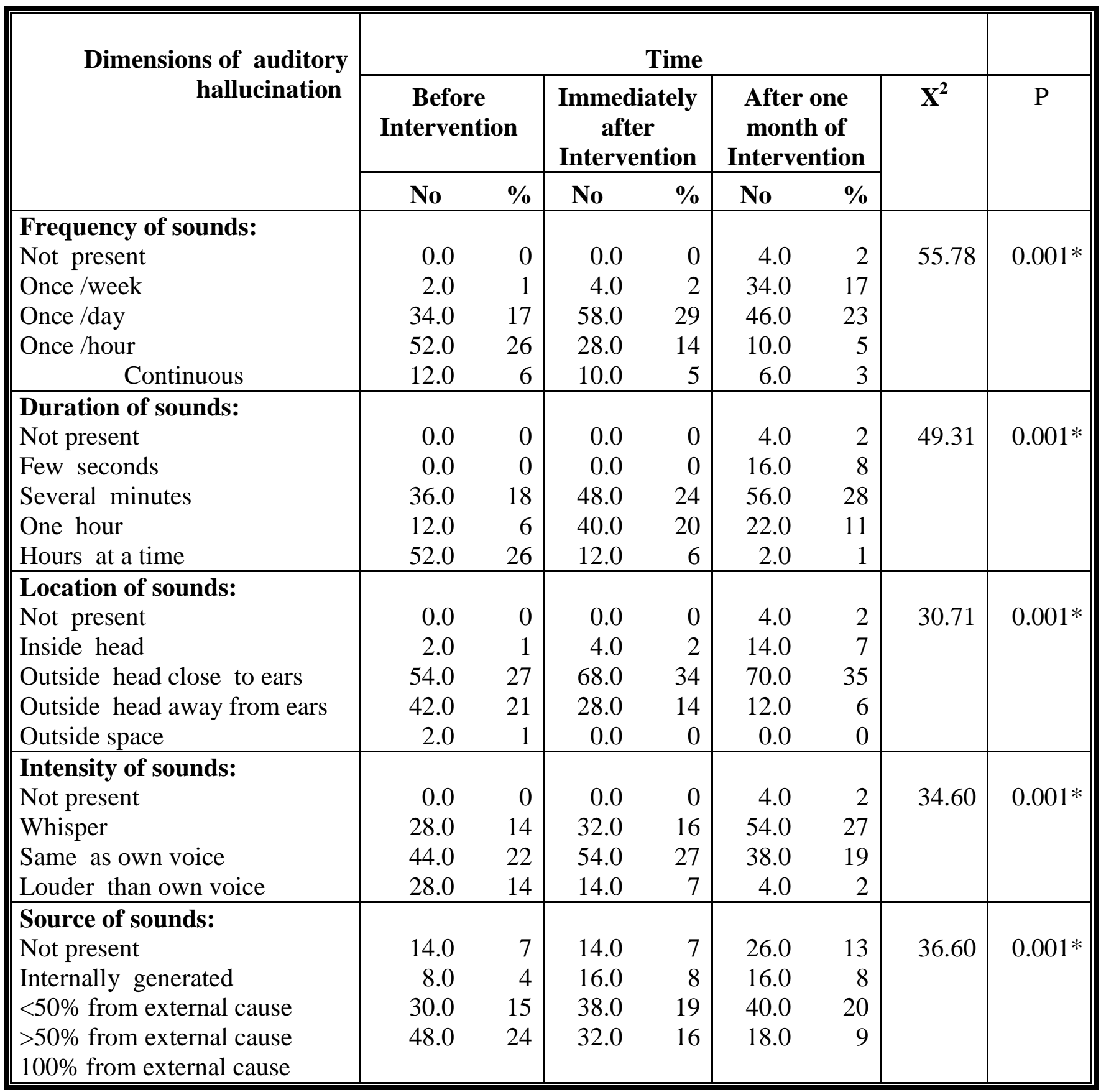

*Significant at $\mathbf{p}<\mathbf{0 . 0 5}$. 
Table (3): (Continue)

\begin{tabular}{|c|c|c|c|c|c|c|c|c|}
\hline \multirow{3}{*}{$\begin{array}{c}\text { Dimension s of Auditory } \\
\text { hallucination }\end{array}$} & \multicolumn{7}{|c|}{ Time } & \multirow{3}{*}{$\mathrm{P}$} \\
\hline & \multicolumn{2}{|c|}{$\begin{array}{c}\text { Before } \\
\text { Intervention }\end{array}$} & \multicolumn{2}{|c|}{$\begin{array}{c}\text { Immediately } \\
\text { after } \\
\text { Intervention }\end{array}$} & \multicolumn{2}{|c|}{$\begin{array}{c}\text { After one } \\
\text { month of } \\
\text { Intervention } \\
\end{array}$} & \multirow[t]{2}{*}{$\mathrm{X}^{2}$} & \\
\hline & $\mathrm{No}$ & $\%$ & $\mathrm{No}$ & $\%$ & $\mathbf{N}$ & $\%$ & & \\
\hline $\begin{array}{l}\text { Amount of negative content } \\
\text { No unpleasant content } \\
\text { Rarely unpleasant content } \\
\text { Sometimes unpleasant content } \\
\text { Most times unpleasant content } \\
\text { Always unpleasant content } \\
\end{array}$ & $\begin{array}{l}1 \\
1 \\
18 \\
23 \\
7 \\
\end{array}$ & $\begin{array}{l}2.0 \\
2.0 \\
36.0 \\
46.0 \\
14.0\end{array}$ & $\begin{array}{l}1 \\
6 \\
23 \\
19 \\
2 \\
\end{array}$ & $\begin{array}{l}2.0 \\
12.0 \\
46.0 \\
38.0 \\
4.0 \\
\end{array}$ & $\begin{array}{l}6 \\
16 \\
24 \\
4 \\
0 \\
\end{array}$ & $\begin{array}{l}12.0 \\
32.0 \\
48.0 \\
8.0 \\
0.0 \\
\end{array}$ & 66.65 & $0.001 *$ \\
\hline $\begin{array}{l}\text { Degree of negative content: } \\
\text { No unpleasant content } \\
\text { Some degree of negative content } \\
\text { Verbal comments on behavior } \\
\text { Personal verbal abuse } \\
\text { Personal threat to harm self } \\
\end{array}$ & $\begin{array}{l}1 \\
8 \\
15 \\
19 \\
7 \\
\end{array}$ & $\begin{array}{l}2.0 \\
16.0 \\
30.0 \\
38.0 \\
14.0 \\
\end{array}$ & $\begin{array}{l}2 \\
8 \\
21 \\
15 \\
4 \\
\end{array}$ & $\begin{array}{l}4.0 \\
16.0 \\
42.0 \\
30.0 \\
8.0 \\
\end{array}$ & $\begin{array}{l}6 \\
22 \\
13 \\
6 \\
3 \\
\end{array}$ & $\begin{array}{l}12.0 \\
44.0 \\
26.0 \\
12.0 \\
6.0 \\
\end{array}$ & 45.76 & $0.001 *$ \\
\hline $\begin{array}{l}\text { Amount of distress by sounds: } \\
\text { Not distressing } \\
\text { Occasionally distressing } \\
\text { Equal distressing \&not } \\
\text { distressing } \\
\text { Majority of voice distressing } \\
\text { Always distressing } \\
\end{array}$ & $\begin{array}{l}0 \\
2 \\
11 \\
22 \\
15\end{array}$ & $\begin{array}{l}0.0 \\
4.0 \\
22.0 \\
44.0 \\
30.0\end{array}$ & $\begin{array}{l}2 \\
6 \\
23 \\
15 \\
4\end{array}$ & $\begin{array}{l}4.0 \\
12.0 \\
46.0 \\
30.0 \\
8.0\end{array}$ & $\begin{array}{l}9 \\
19 \\
17 \\
3 \\
2\end{array}$ & $\begin{array}{l}18.0 \\
36.0 \\
36.0 \\
6.0 \\
4.0\end{array}$ & 77.58 & $0.001 *$ \\
\hline \begin{tabular}{|l|} 
Intensity of distress by sounds: \\
Not distressing \\
Slightly distressing \\
Distressing to moderate degree \\
Very distressing \\
Extremely distressing \\
\end{tabular} & $\begin{array}{l}0 \\
2 \\
17 \\
24 \\
7 \\
\end{array}$ & $\begin{array}{l}0.0 \\
4.0 \\
34.0 \\
48.0 \\
14.0 \\
\end{array}$ & \begin{tabular}{|l}
1 \\
15 \\
28 \\
5 \\
1 \\
\end{tabular} & $\begin{array}{l}2.0 \\
30.0 \\
56.0 \\
10.0 \\
2.0 \\
\end{array}$ & $\begin{array}{l}13 \\
26 \\
9 \\
2 \\
0 \\
\end{array}$ & $\begin{array}{l}26.0 \\
52.0 \\
18.0 \\
4.0 \\
0.0 \\
\end{array}$ & 88.55 & $0.001 *$ \\
\hline $\begin{array}{l}\text { Disturbed life by sounds: } \\
\text { No disruption } \\
\text { Minimal amount of disruption } \\
\text { Moderate amount of disruption } \\
\text { Sever disruption } \\
\text { Complete disruption } \\
\end{array}$ & \begin{tabular}{|l}
0 \\
16 \\
22 \\
11 \\
1 \\
\end{tabular} & $\begin{array}{l}0.0 \\
32.0 \\
44.0 \\
22.0 \\
2.0 \\
\end{array}$ & \begin{tabular}{|l|}
2 \\
17 \\
22 \\
9 \\
0 \\
\end{tabular} & $\begin{array}{l}4.0 \\
34.0 \\
44.0 \\
18.0 \\
0.0 \\
\end{array}$ & $\begin{array}{l}18 \\
22 \\
6 \\
4 \\
0 \\
\end{array}$ & $\begin{array}{l}36.0 \\
44.0 \\
12.0 \\
8.0 \\
0.0 \\
\end{array}$ & 60.20 & $0.001 *$ \\
\hline $\begin{array}{l}\text { Level of control on sounds: } \\
\text { Complete control } \\
\text { Some control half of time } \\
\text { Some control occasionally } \\
\text { No control } \\
\end{array}$ & $\begin{array}{l}0 \\
2 \\
11 \\
37 \\
\end{array}$ & $\begin{array}{l}0.0 \\
4.0 \\
22.0 \\
74.0 \\
\end{array}$ & $\begin{array}{l}0 \\
6 \\
25 \\
19 \\
\end{array}$ & $\begin{array}{l}0.0 \\
12.0 \\
50.0 \\
38.0 \\
\end{array}$ & $\begin{array}{l}1 \\
20 \\
22 \\
7\end{array}$ & $\begin{array}{l}2.0 \\
40.0 \\
44.0 \\
14.0 \\
\end{array}$ & 56.75 & $0.001 *$ \\
\hline
\end{tabular}

*Significant at $\mathbf{p}<0.05$ 
Table (4): Percentage distribution of studied patients in relation to using physiological methods of coping strategies for treatment of auditory hallucinations $(n=50)$.

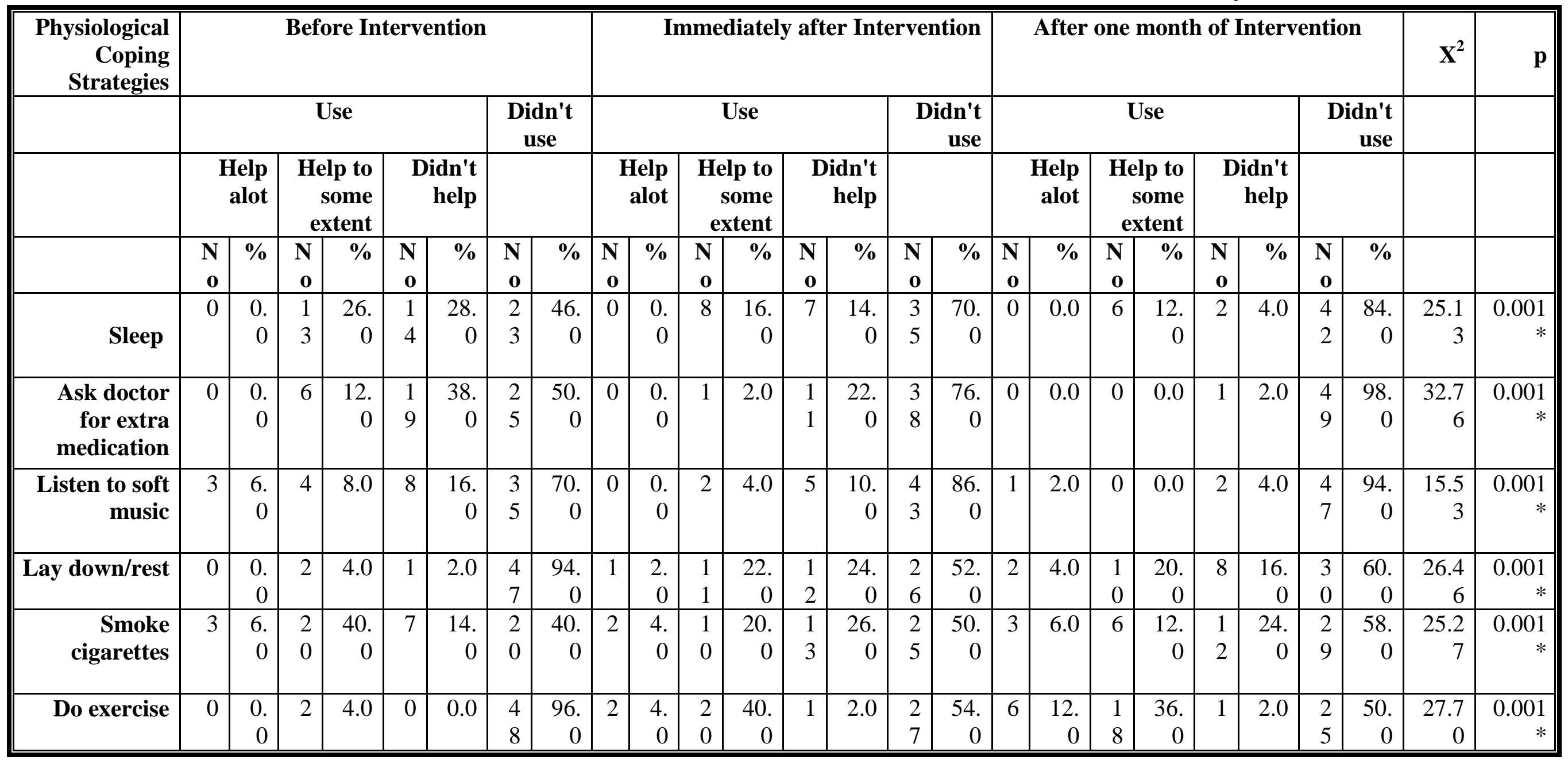




\begin{tabular}{|r|r|r|r|r|r|r|r|r|r|r|r|r|r|r|r|r|r|r|r|r|r|r|r|r|r|r|}
\hline Walk & 4 & 8. & 2 & 54. & 1 & 2.0 & 1 & 36. & 1 & 2. & 3 & 60. & 2 & 4.0 & 1 & 34. & 3 & 6.0 & 1 & 26. & 1 & 32. & 1 & 36. & 25.2 & 0.001 \\
& & 0 & 7 & 0 & & & 8 & 0 & & 0 & 0 & 0 & & & 7 & 0 & & 3 & 0 & 6 & 0 & 8 & 0 & 1 & $*$ \\
\hline
\end{tabular}

*Significant at $\mathbf{p}<0.05$ 
Table (5): Percentage distribution of studied patients in relation to using cognitive methods of coping strategies for treatment of auditory hallucinations $(n=50)$.

\begin{tabular}{|c|c|c|c|c|c|c|c|c|c|c|c|c|c|c|c|c|c|c|c|c|c|c|c|c|c|c|c|c|c|}
\hline \multirow{4}{*}{$\begin{array}{r}\text { Cognitive } \\
\text { Coping } \\
\text { Strategies } \\
\end{array}$} & \multicolumn{9}{|c|}{ Before Intervention } & \multicolumn{9}{|c|}{ Immediately after Intervention } & \multicolumn{9}{|c|}{ After one month of Intervention } & \multirow{2}{*}{$\mathrm{X}^{2}$} & \multirow{2}{*}{$\mathbf{p}$} \\
\hline & \multicolumn{6}{|c|}{ Use } & \multicolumn{3}{|c|}{$\begin{array}{r}\text { Didn't } \\
\text { use }\end{array}$} & \multicolumn{7}{|c|}{ Use } & \multicolumn{2}{|c|}{$\begin{array}{r}\text { Didn' } \\
\text { uS }\end{array}$} & \multicolumn{7}{|c|}{ Use } & \multicolumn{2}{|c|}{$\begin{array}{r}\text { Didn't } \\
\text { use }\end{array}$} & & \\
\hline & \multicolumn{2}{|c|}{$\begin{array}{r}\text { Help a } \\
\text { lot }\end{array}$} & \multicolumn{2}{|c|}{$\begin{array}{r}\text { Help to } \\
\text { some } \\
\text { extent }\end{array}$} & \multicolumn{2}{|c|}{$\begin{array}{r}\text { Didn't } \\
\text { help }\end{array}$} & & & & \multicolumn{2}{|c|}{$\begin{array}{r}\text { Help a } \\
\text { lot }\end{array}$} & \multicolumn{2}{|c|}{$\begin{array}{r}\text { Help to } \\
\text { some } \\
\text { extent }\end{array}$} & \multicolumn{3}{|c|}{$\begin{array}{r}\text { Didn't } \\
\text { help }\end{array}$} & & & \multicolumn{3}{|c|}{$\begin{array}{r}\text { Help a } \\
\text { lot }\end{array}$} & \multicolumn{2}{|c|}{$\begin{array}{r}\text { Help to } \\
\text { some } \\
\text { extent }\end{array}$} & \multicolumn{2}{|c|}{$\begin{array}{r}\text { Didn't } \\
\text { help }\end{array}$} & & & & \\
\hline & $\begin{array}{r}\mathbf{N} \\
\mathbf{0}\end{array}$ & $\%$ & $\begin{array}{l}\mathbf{N} \\
\mathbf{0}\end{array}$ & $\%$ & $\mathbf{N o}$ & c & & $\begin{array}{l}\mathbf{N} \\
\mathbf{0}\end{array}$ & $\%$ & $\begin{array}{c}\mathbf{N} \\
\mathbf{o}\end{array}$ & $\%$ & $\mathrm{~N}$ & 9 & & v & $\%$ & $\begin{array}{l}\mathbf{N} \\
\mathbf{0}\end{array}$ & & & $\begin{array}{l}\mathbf{N} \\
\mathbf{0}\end{array}$ & $\%$ & $\begin{array}{r}\mathbf{N} \\
\mathbf{0}\end{array}$ & $\%$ & \begin{tabular}{c|}
$\mathbf{N}$ \\
$\mathbf{0}$
\end{tabular} & $\%$ & No & $\%$ & & \\
\hline $\begin{array}{r}\text { React } / \text { talk } \\
\text { to voices }\end{array}$ & $\begin{array}{l}4 \\
7\end{array}$ & $\begin{array}{r}94 . \\
0\end{array}$ & 0 & 0.0 & 3 & 6 & & 0 & 0.0 & 1 & 2.0 & 6 & 12 & & 1 & 22. & $\begin{array}{l}3 \\
2\end{array}$ & & & 3 & 6.0 & $\begin{array}{l}1 \\
3\end{array}$ & $\begin{array}{r}26 . \\
0\end{array}$ & $\begin{array}{l}1 \\
6\end{array}$ & $\begin{array}{r}32 . \\
0\end{array}$ & 18 & $\begin{array}{r}36 . \\
0\end{array}$ & $\begin{array}{r}58.5 \\
1\end{array}$ & $0.001 *$ \\
\hline $\begin{array}{r}\text { Selective } \\
\text { listen to } \\
\text { voices }\end{array}$ & 0 & 0.0 & 7 & 14.0 & 3 & 1 & & $\begin{array}{l}3 \\
8\end{array}$ & $\begin{array}{r}76 . \\
0\end{array}$ & 0 & 0.0 & 8 & 10 & & 4 & 8.0 & $\begin{array}{l}3 \\
8\end{array}$ & & & 2 & 4.0 & $\begin{array}{l}1 \\
1\end{array}$ & $\begin{array}{r}22 . \\
0\end{array}$ & $\begin{array}{l}1 \\
9\end{array}$ & $\begin{array}{r}38 . \\
0\end{array}$ & 18 & $\begin{array}{r}36 . \\
0\end{array}$ & $\begin{array}{r}17.6 \\
2\end{array}$ & $0.001 *$ \\
\hline $\begin{array}{r}\text { Listen to } \\
\text { voices }\end{array}$ & 2 & 4.0 & $\begin{array}{l}1 \\
1\end{array}$ & 22.0 & 15 & 3 & & $\begin{array}{l}1 \\
8\end{array}$ & $\begin{array}{r}36 . \\
0\end{array}$ & 5 & $\begin{array}{r}10 . \\
0\end{array}$ & 0 & 0. & & 7 & $\begin{array}{r}14 . \\
0\end{array}$ & $\begin{array}{l}3 \\
8\end{array}$ & 7 & & 1 & 2.0 & 1 & 2.0 & 3 & 6.0 & 45 & $\begin{array}{r}90 . \\
0\end{array}$ & $\begin{array}{r}38.6 \\
2\end{array}$ & $0.001 *$ \\
\hline $\begin{array}{r}\text { Ask oneself } \\
\text { to calm } \\
\text { down }\end{array}$ & 1 & 2.0 & 0 & 0.0 & 2 & 4 & & $\begin{array}{l}4 \\
7\end{array}$ & $\begin{array}{r}94 . \\
0\end{array}$ & 2 & 4.0 & 1 & 3 & & 7 & $\begin{array}{r}14 . \\
0\end{array}$ & $\begin{array}{l}2 \\
5\end{array}$ & 5 & & 1 & 2.0 & $\begin{array}{l}1 \\
6\end{array}$ & $\begin{array}{r}32 . \\
0\end{array}$ & 4 & 8.0 & 29 & $\begin{array}{r}58 . \\
0\end{array}$ & $\begin{array}{r}24.5 \\
0\end{array}$ & $0.001^{*}$ \\
\hline $\begin{array}{r}\text { Ignore the } \\
\text { voices }\end{array}$ & 0 & 0.0 & 6 & 12.0 & 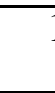 & 2. & & $\begin{array}{l}4 \\
3 \\
\end{array}$ & $\begin{array}{r}86 . \\
0\end{array}$ & 7 & $\begin{array}{r}14 . \\
0\end{array}$ & 2 & 5 & & 3 & 6.0 & $\begin{array}{l}1 \\
3\end{array}$ & 2 & & $\begin{array}{l}1 \\
7\end{array}$ & $\begin{array}{r}34 . \\
0\end{array}$ & $\begin{array}{l}2 \\
1\end{array}$ & $\begin{array}{r}42 . \\
0\end{array}$ & 1 & 2.0 & 11 & $\begin{array}{r}22 . \\
0\end{array}$ & $\begin{array}{r}58.6 \\
6 \\
\end{array}$ & $0.001 *$ \\
\hline $\begin{array}{r}\text { Clarify } \\
\text { voices and } \\
\text { say to } \\
\text { oneself it } \\
\text { isn't true }\end{array}$ & $\overline{0}$ & 0.0 & 1 & 2.0 & 2 & 4 & & $\begin{array}{l}4 \\
7\end{array}$ & $\begin{array}{r}94 . \\
0\end{array}$ & $\overline{0}$ & 0.0 & 1 & $\overline{3}$ & & 3 & 6.0 & $\begin{array}{l}2 \\
8\end{array}$ & 5 & & 7 & $\begin{array}{r}14 . \\
0\end{array}$ & $\begin{array}{l}1 \\
8\end{array}$ & $\begin{array}{r}36 . \\
0\end{array}$ & 2 & 4.0 & 23 & $\begin{array}{r}46 . \\
0\end{array}$ & $\begin{array}{r}29.1 \\
5\end{array}$ & $0.001^{*}$ \\
\hline $\begin{array}{l}\text { Shoot and } \\
\text { scream at }\end{array}$ & 3 & 6.0 & $\begin{array}{l}2 \\
1 \\
\end{array}$ & 42.0 & ( & 1 & & $\begin{array}{l}2 \\
0 \\
\end{array}$ & $\begin{array}{r}40 . \\
0\end{array}$ & 0 & 0.0 & 2 & 2 & & 5 & $\begin{array}{r}10 . \\
0\end{array}$ & 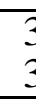 & & & 1 & 2.0 & 1 & 2.0 & 5 & $\begin{array}{r}10 . \\
0\end{array}$ & 43 & $\begin{array}{r}86 . \\
0 \\
\end{array}$ & $\begin{array}{r}39.8 \\
5 \\
\end{array}$ & $0.001^{*}$ \\
\hline
\end{tabular}




1

\begin{tabular}{l|l|l|l|l|l|l}
\hline & & & & & & \\
\hline
\end{tabular}

$+$

$|+|$

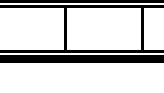

\section{*Significant at p $<0.05$}

Table (5): (Continue)

\begin{tabular}{|c|c|c|c|c|c|c|c|c|c|c|c|c|c|c|c|c|c|c|c|c|c|c|c|c|c|c|c|c|c|c|}
\hline \multirow{4}{*}{$\begin{array}{r}\text { Cognitive } \\
\text { Coping } \\
\text { Strategies } \\
\end{array}$} & \multicolumn{9}{|c|}{ Before Intervention } & \multicolumn{10}{|c|}{ Immediately after Intervention } & \multicolumn{9}{|c|}{ After one month of Intervention } & \multirow{2}{*}{$\mathbf{X}^{2}$} & \\
\hline & \multicolumn{6}{|c|}{ Use } & \multirow{2}{*}{\multicolumn{3}{|c|}{$\begin{array}{r}\text { Didn't } \\
\text { use } \\
\end{array}$}} & \multicolumn{7}{|c|}{ Use } & \multirow{2}{*}{\multicolumn{3}{|c|}{$\begin{array}{r}\text { Didn't } \\
\text { use } \\
\end{array}$}} & \multicolumn{6}{|c|}{ Use } & \multicolumn{3}{|c|}{$\begin{array}{r}\text { Didn't } \\
\text { use }\end{array}$} & & \\
\hline & \multicolumn{2}{|c|}{$\begin{array}{r}\text { Help a } \\
\text { lot }\end{array}$} & \multicolumn{2}{|c|}{$\begin{array}{r}\text { Help to } \\
\text { some } \\
\text { extent }\end{array}$} & \multicolumn{2}{|c|}{$\begin{array}{r}\text { Didn't } \\
\text { help }\end{array}$} & & & & \multicolumn{2}{|c|}{$\begin{array}{r}\text { Help a } \\
\text { lot }\end{array}$} & \multicolumn{3}{|c|}{$\begin{array}{r}\text { Help to } \\
\text { some } \\
\text { extent }\end{array}$} & \multicolumn{2}{|c|}{$\begin{array}{r}\text { Didn't } \\
\text { help }\end{array}$} & & & & \multicolumn{2}{|c|}{$\begin{array}{r}\text { Help a } \\
\text { lot }\end{array}$} & \multicolumn{2}{|c|}{$\begin{array}{r}\text { Help to } \\
\text { some } \\
\text { extent }\end{array}$} & \multicolumn{3}{|c|}{$\begin{array}{r}\text { Didn't } \\
\text { help }\end{array}$} & & & & \\
\hline & No & $\%$ & No & $\%$ & $\mathbf{N}$ & & & No & $\%$ & No & $\%$ & $\mathrm{Nc}$ & & $\%$ & No & $\%$ & & No & $\%$ & No & $\%$ & No & $\%$ & No & 0 & & No & $\%$ & & \\
\hline $\begin{array}{r}\text { Say go } \\
\text { away and } \\
\text { stop to } \\
\text { voices }\end{array}$ & 0 & 0.0 & 0 & 0.0 & 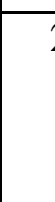 & 4 & & 48 & 96.0 & 2 & 4.0 & 12 & & 28.0 & 1 & 2. & & 33 & 66.0 & 2 & 4.0 & 19 & 38.0 & 2 & 4. & & 27 & 54.0 & 24.82 & $0.001 *$ \\
\hline $\begin{array}{l}\text { Read } \\
\text { aloud }\end{array}$ & 0 & 0.0 & 2 & 4.0 & 2 & & & 46 & 92.0 & 1 & 2.0 & 11 & & 22.0 & $\overline{4}$ & 8. & & 34 & 68.0 & 3 & 6.0 & 9 & 18.0 & 3 & 6. & & 35 & 70.0 & \begin{tabular}{|l|}
11.04 \\
\end{tabular} & $0.004 *$ \\
\hline $\begin{array}{r}\text { Think in } \\
\text { another } \\
\text { thing } \\
\text { except } \\
\text { voice }\end{array}$ & 0 & 0.0 & 0 & 0.0 & 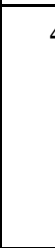 & & & 46 & 92.0 & 1 & 2.0 & 33 & & 66.0 & 3 & 6. & & 13 & 26.0 & 1 & 2.0 & 23 & 46.0 & 2 & 4. & & 24 & 48.0 & 45.92 & $0.001 *$ \\
\hline $\begin{array}{r}\text { Repeat } \\
\text { short }\end{array}$ & 6 & 12.0 & 1 & 2.0 & 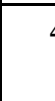 & & & 39 & 68.0 & 12 & 24.0 & 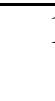 & & 2.0 & 4 & 8. & & 33 & 66.0 & 11 & 22.0 & 2 & 4.0 & 2 & 4. & & 35 & 70.0 & 2.988 & 0.22 \\
\hline
\end{tabular}

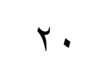




\begin{tabular}{|r|r|r|l|l|l|l|l|l|l|l|l|l|l|l|l|l|l|l|l|l|l|l|l|}
\hline $\begin{array}{r}\text { sentences } \\
\text { and or } \\
\text { count } \\
\text { numbers } \\
\text { sub } \\
\text { vocally }\end{array}$ & & & & & & & & & & & & & & & & & & & & & & & \\
\hline
\end{tabular}

*Significant at $\mathbf{p}<0.05$ 
Table (6): Percentage distribution of studied patients regarding to using behavioral methods of coping strategies treatment of auditory hallucinations $(\mathrm{n}=50)$.

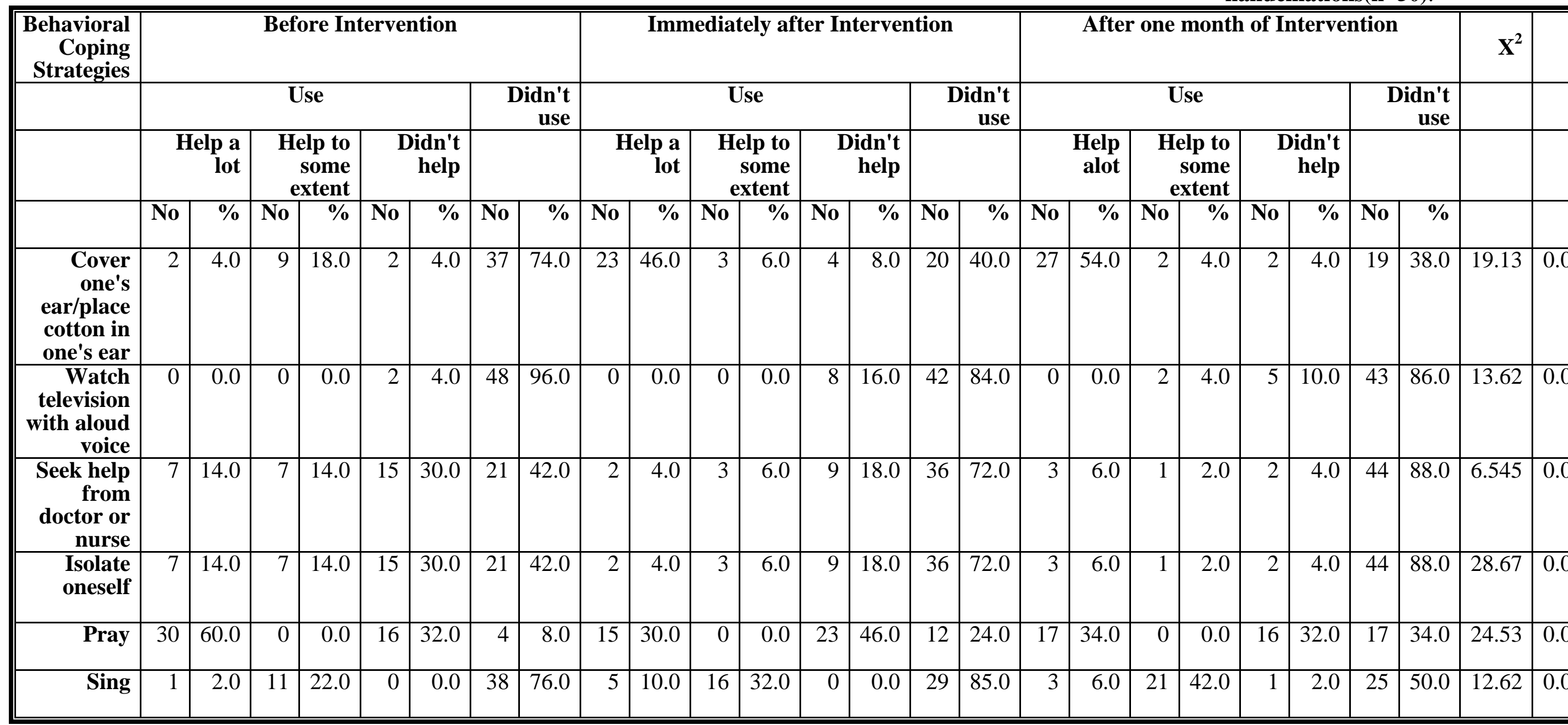




\begin{tabular}{|r|r|r|r|r|r|r|r|r|r|r|r|r|r|r|r|r|r|r|r|r|r|r|r|r|r|r|r|r|r|}
\hline $\begin{array}{r}\text { Go to } \\
\text { crowded } \\
\text { places }\end{array}$ & 3 & 6.0 & 0 & 0.0 & 4 & 8 & 43 & 86.0 & 4 & 8.0 & 0 & 0.0 & 2 & 4.0 & 44 & 88.0 & 7 & 14.0 & 0 & 0.0 & 2 & 4.0 & 41 & 82.0 & 0.565 & 0. \\
\hline Paint & 6 & 12.0 & 1 & 2.0 & 0 & 0.0 & 43 & 86.0 & 12 & 24.0 & 20 & 40.0 & 1 & 2.0 & 17 & 34.0 & 10 & 20.0 & 18 & 36.0 & 0 & 0.0 & 22 & 44.0 & 26.69 & 0.0 \\
\hline Eat & 2 & 4.0 & 7 & 14.0 & 5 & 10.0 & 36 & 72.0 & 4 & 8.0 & 4 & 8.0 & 1 & 2.0 & 41 & 82.0 & 3 & 6.0 & 3 & 6.0 & 1 & 2.0 & 43 & 86.0 & 1.810 & 0.0 \\
\hline
\end{tabular}

*Significant at $\mathbf{p}<0.05$

Table (6): (Continue)

\begin{tabular}{|c|c|c|c|c|c|c|c|c|c|c|c|c|c|c|c|c|c|c|c|c|c|c|c|c|}
\hline \multirow{4}{*}{$\begin{array}{r}\text { Behavioral } \\
\text { Coping } \\
\text { Strategies } \\
\end{array}$} & \multicolumn{7}{|c|}{ Before Intervention } & \multicolumn{8}{|c|}{ Immediately after Intervention } & \multicolumn{8}{|c|}{ After one month of Intervention } & \multirow{2}{*}{$\mathbf{X}^{2}$} \\
\hline & \multicolumn{5}{|c|}{ Use } & \multicolumn{2}{|c|}{$\begin{array}{r}\text { Didn't } \\
\text { use }\end{array}$} & \multicolumn{6}{|c|}{ Use } & \multicolumn{2}{|c|}{$\begin{array}{r}\text { Didn't } \\
\text { use }\end{array}$} & \multicolumn{6}{|c|}{ Use } & \multicolumn{2}{|c|}{$\begin{array}{r}\text { Didn't } \\
\text { use }\end{array}$} & \\
\hline & $\begin{array}{r}\text { Help a } \\
\text { lot }\end{array}$ & & $\begin{array}{l}\text { to } \\
\text { ome } \\
\text { tent } \\
\end{array}$ & & $\begin{array}{l}\text { dn't } \\
\text { help }\end{array}$ & & & & $\begin{array}{l}\text { lp a } \\
\text { lot }\end{array}$ & & $\begin{array}{l}\text { p to } \\
\text { ome } \\
\text { tent } \\
\end{array}$ & & $\begin{array}{l}\text { In't } \\
\text { lelp }\end{array}$ & & & & $\begin{array}{l}\text { lp a } \\
\text { lot }\end{array}$ & & $\begin{array}{l}\text { to } \\
\text { me } \\
\text { ent }\end{array}$ & & $\begin{array}{l}\text { dn't } \\
\text { help }\end{array}$ & & & \\
\hline & No & No & $\%$ & No & $\%$ & No & $\%$ & No & $\%$ & No & $\%$ & No & $\%$ & No & $\%$ & No & $\%$ & No & $\%$ & No & $\%$ & No & $\%$ & \\
\hline
\end{tabular}




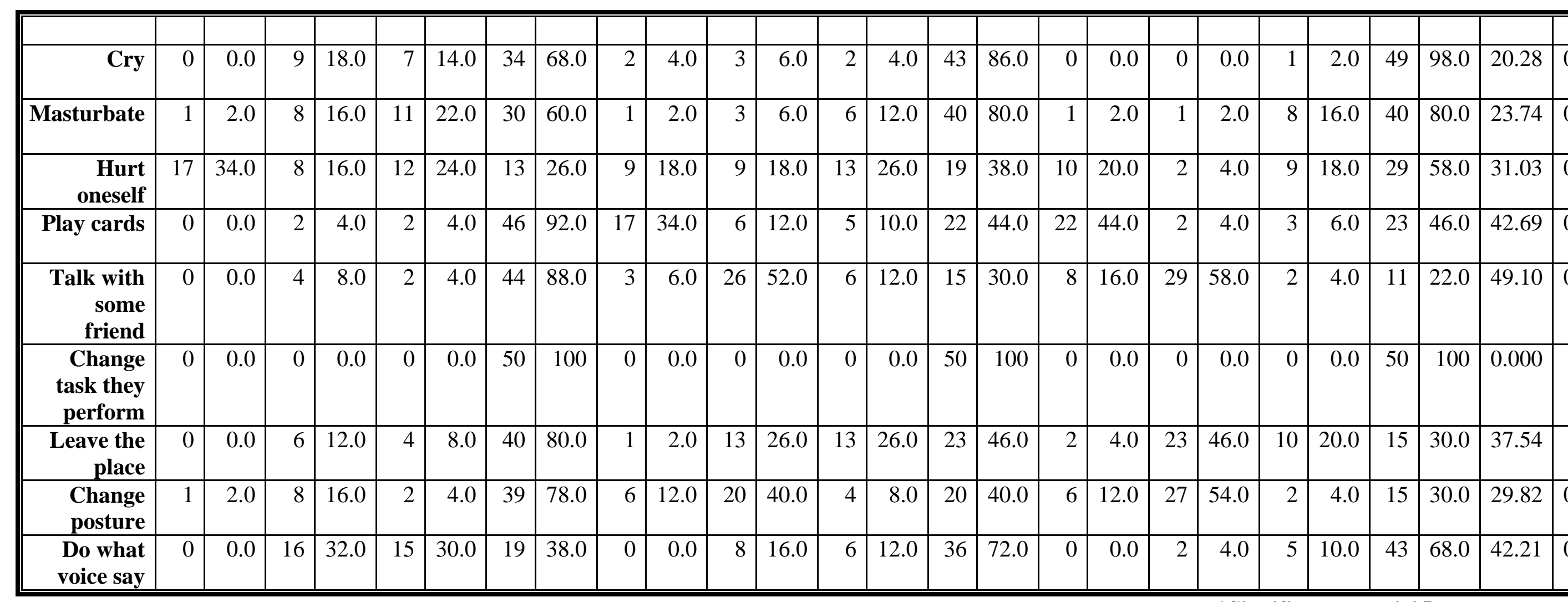


Table (7): Percentage distribution of studied patients regarding to using other coping strategies for auditory hallucinations(n=50).

\begin{tabular}{|c|c|c|c|c|c|c|c|c|c|c|c|c|c|c|c|c|c|c|c|c|c|c|c|c|c|c|}
\hline \multirow{4}{*}{\begin{tabular}{r|} 
Other Coping \\
Strategies \\
\end{tabular}} & \multicolumn{8}{|c|}{ Before Intervention } & \multicolumn{8}{|c|}{ Immediately after Intervention } & \multicolumn{8}{|c|}{ After one monthof Intervention } & \multirow{2}{*}{$\mathbf{X}^{2}$} & \multirow{2}{*}{$\mathbf{P}$} \\
\hline & \multicolumn{6}{|c|}{ Use } & \multicolumn{2}{|c|}{$\begin{array}{r}\text { Didn't } \\
\text { use }\end{array}$} & \multicolumn{6}{|c|}{ Use } & \multicolumn{2}{|c|}{$\begin{array}{r}\text { Didn't } \\
\text { use }\end{array}$} & \multicolumn{6}{|c|}{ Use } & \multicolumn{2}{|c|}{$\begin{array}{r}\text { Didn't } \\
\text { use }\end{array}$} & & \\
\hline & \multicolumn{2}{|c|}{$\begin{array}{l}\text { Help } \\
\text { a lot }\end{array}$} & \multicolumn{2}{|c|}{$\begin{array}{r}\text { Help } \\
\text { to } \\
\text { some } \\
\text { extent }\end{array}$} & \multicolumn{2}{|c|}{$\begin{array}{r}\text { Didn't } \\
\text { help }\end{array}$} & & & \multicolumn{2}{|c|}{$\begin{array}{r}\text { Help a } \\
\text { lot }\end{array}$} & \multicolumn{2}{|c|}{$\begin{array}{r}\text { Help to } \\
\text { some } \\
\text { extent }\end{array}$} & \multicolumn{2}{|c|}{$\begin{array}{r}\text { Didn't } \\
\text { help }\end{array}$} & & & \multicolumn{2}{|c|}{$\begin{array}{r}\text { Help } \\
\text { alot }\end{array}$} & \multicolumn{2}{|c|}{$\begin{array}{r}\text { Help to } \\
\text { some } \\
\text { extent }\end{array}$} & \multicolumn{2}{|c|}{$\begin{array}{r}\text { Didn't } \\
\text { help }\end{array}$} & & & & \\
\hline & $\begin{array}{c}\mathbf{N} \\
\mathbf{0}\end{array}$ & $\%$ & $\begin{array}{r}\mathbf{N} \\
\mathbf{0}\end{array}$ & $\%$ & $\begin{array}{r}\mathbf{N} \\
\mathbf{0}\end{array}$ & $\%$ & $\begin{array}{r}\mathbf{N} \\
\mathbf{0}\end{array}$ & $\%$ & $\begin{array}{r}\mathbf{N} \\
\mathbf{0}\end{array}$ & $\%$ & $\begin{array}{r}\mathbf{N} \\
\mathbf{0}\end{array}$ & $\%$ & $\begin{array}{r}\mathbf{N} \\
\mathbf{0}\end{array}$ & $\%$ & $\begin{array}{r}\mathbf{N} \\
\mathbf{0}\end{array}$ & $\%$ & $\begin{array}{r}\mathbf{N} \\
\mathbf{0}\end{array}$ & $\%$ & \begin{tabular}{c|}
$\mathbf{N}$ \\
$\mathbf{0}$
\end{tabular} & $\%$ & $\begin{array}{r}\mathbf{N} \\
\mathbf{0}\end{array}$ & $\%$ & $\begin{array}{l}\mathbf{N} \\
\mathbf{0}\end{array}$ & $\%$ & & \\
\hline $\begin{array}{r}\text { Using of } \\
\text { prescribed } \\
\text { medication }\end{array}$ & 0 & $\begin{array}{r}0 . \\
0\end{array}$ & 0 & 0.0 & 0 & 0.0 & $\begin{array}{l}5 \\
0\end{array}$ & $\begin{array}{r}10 \\
0\end{array}$ & 7 & $\begin{array}{r}14 . \\
0\end{array}$ & $\begin{array}{l}1 \\
8\end{array}$ & $\begin{array}{r}36 . \\
0\end{array}$ & 3 & 6.0 & $\begin{array}{l}2 \\
2\end{array}$ & $\begin{array}{r}44 . \\
0\end{array}$ & 5 & $\begin{array}{r}10 . \\
0\end{array}$ & $\begin{array}{l}1 \\
8\end{array}$ & $\begin{array}{r}36 . \\
0\end{array}$ & 1 & 2.0 & $\begin{array}{l}2 \\
6\end{array}$ & $\begin{array}{r}52 . \\
0\end{array}$ & $\begin{array}{r}42.3 \\
3\end{array}$ & $0.001 *$ \\
\hline $\begin{array}{r}\text { Practice deep } \\
\text { breathing exercise }\end{array}$ & 0 & $\begin{array}{r}0 . \\
0 \\
\end{array}$ & 0 & 0.0 & 0 & 0.0 & $\begin{array}{l}5 \\
0\end{array}$ & $\begin{array}{r}10 \\
0\end{array}$ & $\begin{array}{l}1 \\
6 \\
\end{array}$ & $\begin{array}{r}32 . \\
0\end{array}$ & $\begin{array}{l}2 \\
3 \\
\end{array}$ & $\begin{array}{r}46 . \\
0 \\
\end{array}$ & 5 & $\begin{array}{r}10 . \\
0\end{array}$ & 6 & $\begin{array}{r}12 . \\
0\end{array}$ & $\begin{array}{l}1 \\
2 \\
\end{array}$ & $\begin{array}{r}24 . \\
0\end{array}$ & $\begin{array}{l}1 \\
7 \\
\end{array}$ & $\begin{array}{r}34 . \\
0\end{array}$ & 5 & $\begin{array}{r}10 . \\
0 \\
\end{array}$ & $\begin{array}{l}1 \\
6 \\
\end{array}$ & $\begin{array}{r}32 . \\
0\end{array}$ & $\begin{array}{r}70.3 \\
2 \\
\end{array}$ & $0.001 *$ \\
\hline $\begin{array}{r}\text { Practice } \\
\text { progressive } \\
\text { relaxation } \\
\text { technique }\end{array}$ & 0 & $\begin{array}{r}0 . \\
0\end{array}$ & 0 & 0.0 & 0 & 0.0 & $\begin{array}{l}5 \\
0\end{array}$ & $\begin{array}{r}10 \\
0\end{array}$ & 5 & $\begin{aligned} 10 . \\
0\end{aligned}$ & $\begin{array}{l}1 \\
3\end{array}$ & $\begin{array}{r}26 . \\
0\end{array}$ & 4 & 8.0 & $\begin{array}{l}2 \\
8\end{array}$ & $\begin{array}{r}56 . \\
0\end{array}$ & 4 & 8 & \begin{tabular}{l|}
1 \\
1
\end{tabular} & $\begin{array}{r}22 . \\
0\end{array}$ & 5 & $\begin{array}{r}10 . \\
0\end{array}$ & $\begin{array}{l}3 \\
0\end{array}$ & $\begin{array}{r}60 . \\
0\end{array}$ & $\begin{array}{r}36.0 \\
0\end{array}$ & $0.001 *$ \\
\hline $\begin{array}{r}\text { Using self } \\
\text { monitoring logs } \\
\text { for recording } \\
\text { hallucination } \\
\end{array}$ & 0 & $\begin{array}{r}0 . \\
0\end{array}$ & 0 & 0.0 & 0 & 0.0 & $\begin{array}{l}5 \\
0\end{array}$ & $\begin{array}{r}10 \\
0\end{array}$ & 2 & 4.0 & $\begin{array}{l}1 \\
3\end{array}$ & $\begin{array}{r}26 . \\
0\end{array}$ & 6 & $\begin{array}{r}12 . \\
0\end{array}$ & $\begin{array}{l}2 \\
9\end{array}$ & $\begin{array}{r}58 . \\
0\end{array}$ & 1 & 2.0 & $\begin{array}{l}1 \\
2\end{array}$ & $\begin{array}{r}24 . \\
0\end{array}$ & 3 & 6.0 & $\begin{array}{l}3 \\
4\end{array}$ & $\begin{array}{r}68 . \\
0\end{array}$ & $\begin{array}{r}27.8 \\
0\end{array}$ & $0.001 *$ \\
\hline $\begin{array}{r}\text { Drawing /painting } \\
\text { competition with } \\
\text { colleague } \\
\end{array}$ & 0 & $\begin{array}{r}0 . \\
0\end{array}$ & 0 & 0.0 & 0 & 0.0 & $\begin{array}{l}5 \\
0\end{array}$ & $\begin{array}{r}10 \\
0\end{array}$ & $\begin{array}{l}1 \\
2\end{array}$ & $\begin{array}{r}24 . \\
0\end{array}$ & 4 & 8.0 & 1 & 2.0 & $\begin{array}{l}3 \\
3\end{array}$ & $\begin{array}{r}66 . \\
0\end{array}$ & 9 & $\begin{array}{r}18 . \\
0\end{array}$ & 2 & 4.0 & 1 & 2.0 & $\begin{array}{l}3 \\
8\end{array}$ & $\begin{array}{r}76 . \\
0\end{array}$ & $\begin{array}{r}24.1 \\
1\end{array}$ & $0.001 *$ \\
\hline Reading Quran & 0 & 0. & 0 & 0.0 & 0 & 0.0 & 5 & 10 & 7 & 14. & 9 & 18. & 1 & 2.0 & 3 & 72. & 4 & 8.0 & 1 & 22. & 1 & 2.0 & 3 & 68. & 22.1 & $0.001 *$ \\
\hline
\end{tabular}




\begin{tabular}{|c|c|c|c|c|c|c|c|c|c|c|c|c|c|c|c|c|c|c|c|c|c|c|c|c|c|c|}
\hline & & 0 & & & & & 0 & 0 & & 0 & & 0 & & & $\overline{6}$ & 0 & & & 1 & 0 & & & 4 & 0 & 1 & \\
\hline $\begin{array}{r}\text { Say positive } \\
\text { statement to self }\end{array}$ & 0 & $\begin{array}{r}0 . \\
0\end{array}$ & 0 & 0.0 & 0 & 0.0 & $\begin{array}{l}5 \\
0\end{array}$ & $\begin{array}{r}10 \\
0\end{array}$ & 0 & 0.0 & 5 & $\begin{array}{r}10 . \\
0\end{array}$ & 2 & 4.0 & $\begin{array}{l}4 \\
3\end{array}$ & $\begin{array}{r}82 . \\
0\end{array}$ & 0 & 0.0 & 4 & 8.0 & 2 & 4.0 & $\begin{array}{l}4 \\
4\end{array}$ & $\begin{array}{r}88 . \\
0\end{array}$ & $\begin{array}{r}12.2 \\
9\end{array}$ & $0.002^{*}$ \\
\hline Play domino & 0 & $\begin{array}{r}0 . \\
0\end{array}$ & 0 & 0.0 & 0 & 0.0 & $\begin{array}{l}5 \\
0 \\
\end{array}$ & $\begin{array}{r}10 \\
0 \\
\end{array}$ & 2 & 4.0 & 4 & 8.0 & 0 & 0.0 & $\begin{array}{l}4 \\
4 \\
\end{array}$ & $\begin{array}{r}88 . \\
0\end{array}$ & 1 & 2.0 & 1 & 2.0 & 0 & 0.0 & $\begin{array}{l}4 \\
8 \\
\end{array}$ & $\begin{array}{r}96 . \\
0\end{array}$ & 8.00 & $0.018^{*}$ \\
\hline
\end{tabular}

*Significant at $\mathbf{p}<0.05$

Table (7): (Continue)

\begin{tabular}{|c|c|c|c|c|c|c|c|c|c|c|c|c|c|c|c|c|c|c|c|c|c|c|c|c|c|c|}
\hline \multirow{4}{*}{$\begin{array}{r}\text { Other Coping } \\
\text { Strategies } \\
\end{array}$} & \multicolumn{8}{|c|}{ Before Intervention } & \multicolumn{9}{|c|}{ Immediately after Intervention } & \multicolumn{8}{|c|}{ After one month of Intervention } & \multirow{2}{*}{$\mathbf{X}^{2}$} \\
\hline & \multicolumn{6}{|c|}{ Use } & \multirow{2}{*}{\multicolumn{2}{|c|}{$\begin{array}{r}\text { Didn't } \\
\text { use }\end{array}$}} & \multicolumn{6}{|c|}{ Use } & \multirow{2}{*}{\multicolumn{3}{|c|}{$\begin{array}{r}\text { Didn't } \\
\text { use }\end{array}$}} & \multicolumn{6}{|c|}{ Use } & \multicolumn{2}{|c|}{$\begin{array}{r}\text { Didn't } \\
\text { use }\end{array}$} & \\
\hline & \multicolumn{2}{|c|}{$\begin{array}{r}\text { Help a } \\
\text { lot }\end{array}$} & \multicolumn{2}{|c|}{$\begin{array}{r}\text { Help to } \\
\text { some } \\
\text { extent }\end{array}$} & \multicolumn{2}{|c|}{$\begin{array}{r}\text { Didn't } \\
\text { help }\end{array}$} & & & \multicolumn{2}{|c|}{$\begin{array}{r}\text { Help } \\
\text { alot }\end{array}$} & \multicolumn{2}{|c|}{$\begin{array}{r}\text { Help to } \\
\text { some } \\
\text { extent }\end{array}$} & \multicolumn{2}{|c|}{$\begin{array}{r}\text { Didn't } \\
\text { help }\end{array}$} & & & & \multicolumn{2}{|c|}{$\begin{array}{r}\text { Help } \\
\text { alot }\end{array}$} & \multicolumn{2}{|c|}{$\begin{array}{r}\text { Help to } \\
\text { some } \\
\text { extent }\end{array}$} & \multicolumn{2}{|c|}{$\begin{array}{r}\text { Didn't } \\
\text { help }\end{array}$} & & & \\
\hline & No & $\%$ & No & $\%$ & No & $\%$ & No & $\%$ & No & $\%$ & No & $\%$ & No & $\%$ & $\mathbf{N}$ & & $\%$ & No & $\%$ & No & $\%$ & No & $\%$ & No & $\%$ & \\
\hline $\begin{array}{r}\text { Thinking of a } \\
\text { nice place }\end{array}$ & 0 & 0.0 & 0 & 0.0 & 0 & 0.0 & 50 & 100 & 1 & 2.0 & 3 & 6.0 & 1 & 2.0 & 4 & & 90.0 & 1 & 2.0 & 2 & 4.0 & 1 & 2.0 & 46 & 92.0 & 6.421 \\
\hline $\begin{array}{r}\text { Watch colorful } \\
\text { magazine }\end{array}$ & 0 & 0.0 & 0 & 0.0 & 0 & 0.0 & 50 & 100 & 0 & 0.0 & 6 & 12.0 & 0 & 0.0 & 4 & & 88.0 & 2 & 4.0 & 1 & 2.0 & 0 & 0.0 & 47 & 94.0 & 6.700 \\
\hline Dancing/singing & 0 & 0.0 & 0 & 0.0 & 0 & 0.0 & 50 & 100 & 1 & 2.0 & 5 & 10.0 & 1 & 2.0 & & & 86.0 & 1 & 2.0 & 5 & 10.0 & 1 & 2.0 & 43 & 86.0 & 14.00 \\
\hline $\begin{array}{r}\text { Write } \\
\text { stories/poem }\end{array}$ & 0 & 0.0 & 0 & 0.0 & 0 & 0.0 & 50 & 100 & 2 & 4.0 & 0 & 0.0 & 0 & 0.0 & & & 96.0 & 2 & 4.0 & 0 & 0.0 & 0 & \begin{tabular}{|l|}
0.0 \\
\end{tabular} & 48 & 96.0 & 4.00 \\
\hline
\end{tabular}




\begin{tabular}{||r|r|r|r|r|r|r|r|r|r|r|r|r|r|r|r|r|r|r|r|r|r|r|r|r|r|r|}
\hline & & & & & & & & & & & & & & & & & & & & & & & & & & \\
\hline $\begin{array}{r}\text { Take warm } \\
\text { bath before } \\
\text { sleep }\end{array}$ & 0 & 0.0 & 2 & 4.0 & 2 & 4.0 & 46 & 92.0 & 0 & 0.0 & 0 & 0.0 & 0 & 0.0 & 50 & 100 & 2 & 4.0 & 1 & 2.0 & 1 & 2.0 & 46 & 92.0 & 4.00 \\
\hline $\begin{array}{r}\text { Break the stuff } \\
\text { around me }\end{array}$ & 1 & 2.0 & 5 & 10.0 & 2 & 4.0 & 42 & 84.0 & 2 & 4.0 & 2 & 4.0 & 2 & 4.0 & 44 & 88.0 & 1 & 2.0 & 0 & 0.0 & 2 & 4.0 & 47 & 94.0 & 5.419 & \\
\hline $\begin{array}{r}\text { Drink heavy } \\
\text { tea/coffee }\end{array}$ & 2 & 4.0 & 3 & 6.0 & 2 & 4.0 & 43 & 86.0 & 1 & 2.0 & 2 & 4.0 & 3 & 6.0 & 44 & 88.0 & 4 & 8.0 & 1 & 2.0 & 4 & 8.0 & 41 & 82.0 & 2.00 \\
\hline
\end{tabular}

*Significant at $\mathbf{p}<0.05$ 
Table (8): Comparison of total mean scores of patients' hallucination and coping strategies before and after program implementation

\begin{tabular}{|c|c|c|c|c|c|c|c|c|}
\hline \multirow{3}{*}{$\begin{array}{l}\text { Patients' scores on the } \\
\text { different scales }\end{array}$} & \multicolumn{6}{|c|}{ Mean+SD } & \multirow{3}{*}{$X^{2}$} & \multirow{3}{*}{$\mathrm{P}$} \\
\hline & \multicolumn{2}{|c|}{$\begin{array}{c}\text { Before } \\
\text { intervention }\end{array}$} & \multicolumn{2}{|c|}{$\begin{array}{l}\text { Immediately } \\
\text { after }\end{array}$} & \multicolumn{2}{|c|}{ At follow up } & & \\
\hline & $\mathrm{n}$ & $\%$ & $\mathrm{n}$ & $\%$ & $\mathrm{n}$ & $\%$ & & \\
\hline Hallucination & & & & & & & 57.905 & $0.001 *$ \\
\hline Mild hallucinations & 4 & 8 & 11 & 22 & 36 & 72 & & \\
\hline Moderate & 32 & 64 & 35 & 70 & 10 & 20 & & \\
\hline Severe & 14 & 28 & 4 & 8.0 & 4 & 8 & & \\
\hline Physiological coping & & & & & & & 48.054 & $0.001 *$ \\
\hline Unsuccessful coping & 44 & 88 & 17 & 34 & 12 & 24 & & \\
\hline Partial successful & 6 & 12 & 33 & 66 & 37 & 74 & & \\
\hline Successful coping & 0 & 0.0 & 0 & 0.0 & 1 & 2 & & \\
\hline Cognitive coping & & & & & & & 29.314 & $0.001 *$ \\
\hline Unsuccessful coping & 50 & 100.0 & 29 & 58 & 26 & 52 & & \\
\hline Partial successful coping & 0 & 0.0 & 2 & 40 & 23 & 46 & & \\
\hline Successful coping & 0 & 0.0 & 1 & 2 & 1 & 2 & & \\
\hline Behavioral coping & & & & & & & 54.526 & $0.001 *$ \\
\hline Unsuccessful coping & 50 & 100.0 & 20 & 40 & 16 & 32 & & \\
\hline Partial successful coping & 0 & 0.0 & 30 & 60 & 34 & 68 & & \\
\hline Successful coping & 0 & 0.0 & 0 & 0.0 & 0 & 0.0 & & \\
\hline Total coping & & & & & & & 47.538 & $0.001 *$ \\
\hline Unsuccessful coping & 49 & 98 & 22 & 44 & 16 & 32 & & \\
\hline Partial successful coping & 1 & 2 & 28 & 56 & 34 & 68 & & \\
\hline Successful coping & 0 & 0.0 & 0 & 0.0 & 0 & 0.0 & & \\
\hline
\end{tabular}

*Significant at $\mathbf{p}<0.05$ 
Table (9): Relationship between socio-demographic and clinical data of studied patients and mean hallucination score

\begin{tabular}{|c|c|c|c|c|}
\hline \multirow{2}{*}{$\begin{array}{r}\text { Sociodemographic } \\
\text { and clinical data }\end{array}$} & \multicolumn{2}{|c|}{ Hallucination score } & \multirow{2}{*}{$\mathbf{t} / \mathbf{F}$} & \multirow{2}{*}{$\mathbf{P}$} \\
\hline & Range & Mean_SD & & \\
\hline $\begin{array}{l}\text { Age in years: } \\
\leq 35 \\
>35\end{array}$ & $\begin{array}{l}15-40 \\
17-42\end{array}$ & $\begin{array}{l}29.00 \pm 5.88 \\
30.33 \pm 6.47\end{array}$ & 0.759 & 0.452 \\
\hline $\begin{array}{l}\text { Gender: } \\
\text { Males } \\
\text { Females }\end{array}$ & $\begin{array}{l}15-42 \\
19-40\end{array}$ & $\begin{array}{l}29.74 \pm 6.14 \\
29.19 \pm 6.22\end{array}$ & 0.293 & 0.771 \\
\hline $\begin{array}{l}\text { Residence: } \\
\text { Rural } \\
\text { Urban }\end{array}$ & $\begin{array}{l}15-42 \\
17-40\end{array}$ & $\begin{array}{l}30.45 \pm 6.01 \\
28.11 \pm 6.14\end{array}$ & 1.329 & 0.190 \\
\hline $\begin{array}{l}\text { Employment: } \\
\text { Unemployed } \\
\text { Employed }\end{array}$ & $\begin{array}{l}19-42 \\
15-38\end{array}$ & $\begin{array}{l}30.15 \pm 5.85 \\
28.82 \pm 6.47\end{array}$ & 0.758 & 0.452 \\
\hline $\begin{array}{l}\text { Educational level: } \\
\text { Illiterate } \\
\text { Read and write/primary } \\
\text { Secondary /university } \\
\end{array}$ & $\begin{array}{l}15-42 \\
17-40 \\
19-39 \\
\end{array}$ & $\begin{array}{l}31.79 \pm 6.97 \\
28.89 \pm 5.56 \\
28.47 \pm 5.81 \\
\end{array}$ & 1.332 & 0.274 \\
\hline $\begin{array}{l}\text { Marital status: } \\
\text { Single } \\
\text { Ever married }\end{array}$ & $\begin{array}{l}15-42 \\
17-40\end{array}$ & $\begin{array}{l}30.16 \pm 6.04 \\
28.96 \pm 6.23\end{array}$ & 0.691 & 0.493 \\
\hline $\begin{array}{l}\text { Clinical diagnosis: } \\
\text { Schizophrenia } \\
\text { Mania/depression }\end{array}$ & $\begin{array}{l}15-42 \\
17-34\end{array}$ & $\begin{array}{l}31.68 \pm 5.74 \\
25.06 \pm 4.17\end{array}$ & 4.113 & $0.001 *$ \\
\hline
\end{tabular}

*Significant at $\mathbf{p}<0.05$ 
Table (10): Correlation between total scores of hallucinations and coping strategies in relation to the age at onset of the disease, number of hospitalization and current duration of hospitalization

\begin{tabular}{||l|c|c|c|c|c|c||}
\hline \multirow{2}{*}{\begin{tabular}{c}
\multirow{2}{*}{$\begin{array}{c}\text { Patients scores on } \\
\text { different scales }\end{array}$} \\
\cline { 2 - 7 }
\end{tabular}} & \multicolumn{2}{c|}{$\begin{array}{c}\text { Age at onset of } \\
\text { illness }\end{array}$} & \multicolumn{2}{c|}{$\begin{array}{c}\text { Number of hospital } \\
\text { admissions }\end{array}$} & \multicolumn{2}{c|}{$\begin{array}{c}\text { Current duration } \\
\text { of hospitalization }\end{array}$} \\
\cline { 2 - 7 } & $\mathrm{r}$ & $\mathrm{P}$ & $\mathrm{R}$ & $\mathrm{p}$ & $\mathrm{r}$ & $\mathrm{P}$ \\
\hline Total hallucination score & -0.069 & 0.632 & 0.256 & 0.072 & 0.155 & 0.283 \\
\hline $\begin{array}{l}\text { Physiological coping } \\
\text { score }\end{array}$ & -0.251 & 0.079 & 0.115 & 0.427 & -0.060 & 0.681 \\
\hline Cognitive coping score & 0.008 & 0.956 & -0.039 & 0.789 & -0.067 & 0.643 \\
\hline Behavioral coping score & -0.362 & $0.011^{*}$ & 0.017 & 0.908 & -0.019 & 0.869 \\
\hline $\begin{array}{l}\text { Others methods of } \\
\text { coping score }\end{array}$ & 0.010 & 0.945 & -0.104 & 0.484 & -0.249 & 0.088 \\
\hline Total coping score & -0.295 & $0.044^{*}$ & 0.009 & 0.953 & -0.125 & 0.402 \\
\hline
\end{tabular}




\section{Discussion}

Auditory hallucinations are a frequent and prominent component of psychotic disorders. Auditory hallucinations are unusual experience that can be emotionally stressful and few people equipped to cope with through prior learning. For some people, assistance with learning will be adjunctive to pharmacotherapy whilst for others, coping enhancement ought to be the primary intervention. $^{(12,37,38)}$

In the present study, it was observed that there is a significant improvement in the patients dimensions of auditory hallucinations as frequency, duration, location, control \& loudness of auditory hallucinations, origin of voice, disruption of daily life, amount of distress, intensity of distress due to the auditory hallucinations amount and degree of negative content of voices. This improvement may be due to teaching patients using cognitive and behavioral strategies that increased patients' involvement in assessing their symptoms, practicing management skill and evaluating the outcome from their perspective with the researcher.' In this study the group discussion that was used in this study help patients to be aware of their symptoms and to know that they were not alone.

In addition, activities intervention which are attractive and stimulating for patients as (reading aloud, watching television with loud voices, singing/dancing, playing cards or dominoes, watching colorful magazines, drawing/painting competitions, writing stories and poem. These activities keep patients more contact with reality and distract attention away from hallucinations. It is difficult for patients to hallucinate and to share in reality based activity at the same time. $(39,40)$

This result was congruent with some studies as a study conducted by Bagaul (2012)who revealed that after 1 week of intervention, there is a decline in 9 components of auditory hallucination rating scales (frequency, duration, loudness ,location, belief, origin of voice, amount of negative content ,degree of negative content, amount and intensity of distress disruption of life and control of voices . ${ }^{(41)}$ Another experimental study was conducted by Kanungpairn et al (2007) who evaluate the effects of a symptom management program on auditory hallucinations. The results revealed that the participants who attended the symptom management program experienced a significantly decreased overall scores of the characteristics and severity of auditory hallucinations as (frequency ,duration, intensity, control, distress, and anxiety . ${ }^{(42)}$

It was noticed that after educational program, there is decrease in the number of subject used smoke cigarette, sleeping ask doctor for extra medication. This may be due to that the researcher motivates patients to decrease the use of these strategies through giving bonus, candy, verbal praise and material reward .These results were coincides with a study by Bagaul (2012)who revealed that after application coping strategies program with schizophrenic patients, $22 \%$ of them used sleeping , $32 \%$ of them used asking doctors for extra medications and 38\% used smoking to cope with 
auditory hallucinations. ${ }^{(41)}$ While Fallon (1981)who reported that 53\% of the schizophrenic patients ask the doctors for extra medications to manage auditory hallucinations . ${ }^{(4)}$

The current study showed that application cognitive coping strategies with patients. The result showed that about two thirds of subjects react/ talk to the voices. This result may be probably due to that listening to voices is a common response. Often unconsciously the patient has developed the habit of reacting with voices ,as if the patient was a passive recipient. ${ }^{(21)}$ Some patients claimed that react/talk to voices, technique helps them to decrease fear and anxiety and keeps voices under control. This result came in line with a study by Farhall ,Gehrbe (1992)who reported that interacting with voices was identified as the most common hallucination specific strategy. ${ }^{(44)}$ Another study was conducted by Eman (2008)who revealed that $78 \%$ of schizophrenic patients used react/ talk to voices and shout/scream at voices to manage auditory hallucinations. ${ }^{(25)}$

It was observed that after the training program nearly half of the subject clarify voices and say to oneself ,"it isn't true". Half of them ask themselves to calm down and most of them reported these strategies helping them to some extent. This is may be due to that these cognitive coping methods help to shift patients' attention away from auditory hallucinations. This result was consistent with a study conducted by Naoki, Yoshito (2007)who revealed that $40 \%$ of the studied patients used clarify voices and say to oneself ,"it isn't true" and $47 \%$ of them ask themselves to calm down. ${ }^{(19}$ )

Regarding behavioral coping strategies, the results showed that immediately and after intervention, the majority of patients used "paint" and "talk with someone/friend", and about half of them used "play with cards to cope with the voices. Most of them reported that it helps to some extent. These results could be explained by one of the helpful strategies for intervention with hallucinations which is to engage patients in reality based activity such as painting with bright colors among the group of patients. ${ }^{(45)}$

This result may probably due to encouraging the patients to talk with someone/friend in the ward and play cards among the group with the researcher. This was successful because the verbal interaction reduced auditory hallucinations in patients diagnosed with schizophrenia ${ }^{(46)}$.These results were inconsistent with a study conducted by Eman (2008) that revealed that the majority of the patients used playing cards, one third of them used talking with someone and only a small percentage used painting to cope with the voices. ${ }^{(25)}$

The current study presented that majority of the studied patients immediately \&after the educational program used "deep breathing exercises" and some patients reported that this helps them a lot. The researcher, teaches patients principles of practicing deep breathing exercises and its usefulness showing the video about this technique and allowing them time to practice in group. This may be due to that deep breathing exercises are anxiety reduction approaches. It has been 
found that by systematically reducing anxiety associated with particular stressful situation, there is a corresponding decrease in hallucinatory activity. This result was supported by a study conducted by Singh ,Sharan (2002)who revealed that deep breathing exercises were a strategy favored by most patients $(69 \%)^{(31)}$.

It was found that the mean score of behavioral coping and the total coping score were negatively and significantly related to age at onset of hallucinations. This may be due to that the advanced age person acquire skill, experience to cope with difficult situations than younger age, so patients with early disease onset showed less coping with auditory hallucinations than patients with late disease onset .This agreed with a study done by Ikram (2009)who found that reading aloud was negatively and significantly related to the onset of hallucinations. ${ }^{(47)}$.

\section{Conclusion}

Based on the results of the present study, It can be concluded that a marked decrease in the overall dimensions of auditory hallucination of the studied patients as the result of receiving an educational program about enhancing different coping strategies to cope with auditory hallucinations .The majority of patients were practice some physiological, cognitive and behavior coping which are not knowing to the patients before the educational program.

\section{Recommendations}

In the light of the result of this study the following recommendations are suggested

\section{Recommendations related to patients:}

- A psycho educational session about auditory hallucinations and coping strategies should be provided in a treatment program during patients hospitalization.

- Health education about different coping strategies to deal with auditory hallucinations when rehabilitation of the patients to the community

\section{Recommendations related to patient's family:}

- Developing and implementing educational programs for psychiatric patients' families about auditory hallucinations coping strategies and how to deal with patients having auditory hallucinations.

\section{Recommendations related to hospital staff}

- Develop an educational and training programs for nurses about auditory hallucinations and coping strategies to deal with the hallucinations. 
- Health care providers must learn to work with patients through positive therapeutic relationships and use communication skills to encourage patients to express their experiences about their own symptoms of auditory hallucinations and verbalizing if they feel unwell.

\section{Refrences}

1-Mohr K . Psychiatric Mental Health Nursing evidence based concepts,skill and practice. $7^{\text {th }}$ ed.China: Davis Co., 2009;550.

2-Noreen C, Lawernce E. Psychiatric Mental Health Nursing . $4^{\text {th }}$ ed. Unitated States : Donnelley, Willard Co., 2008;517-520.

3-Choong C, Hunter M, Woodruff P. Auditory hallucinations in those populations that do not suffer from schizophrenia. British Journal of Psychiatry 2007;12(9):206-212.

4-Shahid A, Milapkumar P and Jaymie A. Hallucinations: Common features and causes .Clinical Journal of psychiatry2011;10(11):87-9.

5- Didonna F. Mindfulness-based interventions in an inpatient setting. Clinical handbook of mindfulness. $2^{\text {nd }}$ ed. New York: Mosby Co.,2009;447-452.

6-Braun C, Dumont M, Duval J. Brain modules of hallucination: an analysis of multiple patients with brain lesions. Journal Psychiatry Neuroscience 2007;28(2):432-449.

7-Varese F, Bentall R. The metacognitive beliefs to accent of hallucinatory experiences: a literature review and meta analysis .Clinical Psychiatric Review2011;31(2):850-860.

8-Waters F,Allen P,Aleman A,Woodword T,Johns L. Auditory hallucination in schizophrenic and non schizophrenic populations: a review and integrated model of cognitive mechanism .Schizophrenia Bulletin2012;38(3):68-70.

9- Musiek F, Ballingham B,Liu J, Vasil K. Auditory hallucination : an ediological prespectives. The Hearing Journal2007;60(9):32-44.

10- OulisP,Gournellis R,Konstantakopoulou, Gournellis R, Konstantakopoulos G, MatsoukasT, Michalopoulou P Soldatos C. Clinical dimensions of auditory hallucinations in schizophrenic disorders. ComprehensivePsychiatry2008; 48(4): 337-342.

11- Mary A, Cory G, Rebecca G, Gean R. Mental Health Nursing. $2^{\text {nd }}$ ed. New Jersy: Mass publishing Co., 2008;176-78.

12-Kaplan \& Saddock. Comprehensive Textbook of Psychiatry. $8^{\text {th }}$ ed. Philadelphia: Lippincott Williams \&Wilkins Co., 2005 ;325-330 .

13-Kirk R, John F and Frances S. Assessment auditory hallucinations: a review of assessment tools. Australian Journal of Psychiatry 2010;10(2):729

14-Stress Paul C, Max B. The Omnipotence of voices a cognitive approach to auditory hallucinations. British Journal of Psychiatry 2005;12(6): 164-68. 
15-Rudnick A . Sucide development of a measure to assess coping for auditory hall-ucinations. Australian Journal of Psychology 2006 ;58(2) :93- 6.

16-Suzanne H, Experience and coping with auditory hallucination in first episode psychosis relationship with stress coping. Hong Kong Journal of Psychiatry 2008;18(3):115-120.

17- Andrew E, Gray N, Snowden R. The relationship between trauma and beliefs about hearing voices :a study of psychiatric and non psychiatric voice hearers. Psychological Medicine 2008;38(10):1409-1414.

18-Knudson B, Coyle A. Coping strategies for auditory hallucinations .Counseling psychology quartery2006;12(2):25-38.

19- Naoki H. Yoshito I and Seishu N .Auditory hallucination coping techniques and their relationship to psychotic symptomatology. Psychiatry and Clinical Neurosciences Journal 2007; 61(8):640-45.

20-FallonI, TalbotR. Persistent auditory hallucinations :coping mechanism and implications for management .Psychological medicine 1981;11(2)1:329-339.

21- Laori F.How do auditory verbal hallucination in patients differ from those in non patients .Front Human Neuroscience 2012;22(6):389.

22-Suri R. Making sense of voices , an exploration of meaningfulness of auditory hallucination in schizophrenia. Journal of Humanistic Psychology 2010;51(2):151-161.

23-Ouils P ,Gournellisk R, Konstantakoupoulus G, Matsoukas T, Michalopoulour P ,Lykouras L. Clinical Dimension of auditory hallucination in Schizophrenic disorders .Comprhensive Psychiatry 2007;48(2):337-340.

24-Barbara M, Kenneth I .Devlopment a measure to assess coping for auditory hallucinations .Australian Journal of psychiatry ;2006;58(2): 93-100.

25- Abd Elhay E.S. Self-care symptom management strategies for auditory hallucinations among In patients with schizophrenia. unpublished Master Thesis ,Alexandria University-Faculty of nursing 2008 .

26-Suri R. Making sense of voices, an exploration of meaningfulness of auditory hallucination in schizophrenia. Journal of Humanist

27-Michael H,Peter T, James F. Current Diagnosis and Treatment. $2^{\text {nd }}$ ed.Sin2nd ed2nd ed .gapore : Micgraw hill Co.,2008;639-642.

28-Norman L, Lee H, Carol E.Psychiatric Nursing. 5th ed. Unitated States of America :Louise Co.,2007;668.

29- Frederick J , Cotanch P .Self -help techniques for auditory Hallucination $s$ in schizophrenia. Issue in mental health nursing 
30- Mohr K. Psychiatric Mental Health Nursing . 5 th edition

Philadelphia :Lippincott Williams\&Wilkins,2003;400-403

31- Singh G ,Sharan P .Coping with Hallucinations in Schizophrenia : a correlation -study. -Hong Kong Journal Psychiatry 2002:12 (3):5-11

32- Tsai Y, Ku-Y. Self-care symptom management strategies for auditory hallucinations among In patients with schizophrenia at a veteran's hospital in Tiwan .Archives of psychiatric Nursing November 2006;19(8):197-199

33-Marry A .Psychiatric Nursing .First ed .China :Lippincott William \&Willikins Co.,2012;150160.

34-Robert G, Stephane S .Child Psychiatry. 2nd ed .India: Blackwell publishing Co.,2005;223.

35-Basavanthappa B. Psychiatric Mental Health Nursing . First ed. India: Mosby CO.,2007;388 390.

36- Haddock G. Psychological management of schizophrenia. Mental Health Nursing 1994; 15 (2):34-44.

37- Fiel W. Hearing voices .Journal of Psychosocial Nursing and mental health services;2007;23(1):9-14.

38- -David S,Deborah R.Therapeutic Approaches in Mental Health PsychiatricNursing. $7^{\text {th }}$ ed.London: Davis Co., 2007;340-42.

39- Ellen D, Nicole G, Marjan D. Persistence and outcome of auditory hallucinations in adolescence: A longitudinal general population study of 1800 individuals. Schizophrenia Research2011;127(1):254.

40- Folkman S, Lazarus S, Gruen R Appraisal coping health status and psychological symptoms. Journal of Social Psychology 2000;16(3):119-122. + 164.

41- Bagaul C. Effect of coping strategies on chronic drug resistant auditory hallucinations in schizophrenia: a cross over study. Indian Journal of Psychiatry2012;44(1):26.

42-Kanungpairn T, Sitthimongkol Y, Wattanapailin A, Klainin P. Effects of a symptom management program on auditory hallucinations in Thai outpatients with a diagnosis of schizophrenia 2007;9(1):37-9. 
43- FallonI, Talbot R. Persistent auditory hallucinations: coping mechanism and implications for management. Psychological medicine1981;11(2):329-39.

44- Farhall J, Gehrbe M. Coping with hallucinations. Exploring stress and coping framework. British Journal of Clinical Psychology 1992; 36 (2): 259-261.

45- Ramanathan A. Astudy of coping with auditory hallucinations in schizophrenic. Indian Journal of Psychiatry 1984;26(1):229-231

46- Paul G, Guy F. Exercise therapy for schizophrenia. Indian Journal of psychiatry2010;12(5):316.

47-Ikram I. Coping strategies with auditory hallucinations in schizophrenic patients .American Journal of psychiatry;2009;7(1):32-7. 